\title{
Genome-wide differential gene expression in immortalized DF-1 chicken embryo fibroblast cell line
}

Byung-Whi Kong ${ }^{1 *}$, Jeong Yoon Lee ${ }^{1}$, Walter G Bottje ${ }^{1}$, Kentu Lassiter ${ }^{1}$, Jonghyuk Lee ${ }^{2}$ and Douglas N Foster ${ }^{3}$

\begin{abstract}
Background: When compared to primary chicken embryo fibroblast (CEF) cells, the immortal DF-1 CEF line exhibits enhanced growth rates and susceptibility to oxidative stress. Although genes responsible for cell cycle regulation and antioxidant functions have been identified, the genome-wide transcription profile of immortal DF-1 CEF cells has not been previously reported. Global gene expression in primary CEF and DF-1 cells was performed using a 4X44K chicken oligo microarray.

Results: A total of 3876 differentially expressed genes were identified with a 2 fold level cutoff that included 1706 up-regulated and 2170 down-regulated genes in DF-1 cells. Network and functional analyses using Ingenuity Pathways Analysis (IPA, Ingenuity ${ }^{\circledR}$ Systems, http://www.ingenuity.com) revealed that 902 of 3876 differentially expressed genes were classified into a number of functional groups including cellular growth and proliferation, cell cycle, cellular movement, cancer, genetic disorders, and cell death. Also, the top 5 gene networks with intermolecular connections were identified. Bioinformatic analyses suggested that DF-1 cells were characterized by enhanced molecular mechanisms for cell cycle progression and proliferation, suppressing cell death pathways, altered cellular morphogenesis, and accelerated capacity for molecule transport. Key molecules for these functions include E2F1, BRCA1, SRC, CASP3, and the peroxidases.
\end{abstract}

Conclusions: The global gene expression profiles provide insight into the cellular mechanisms that regulate the unique characteristics observed in immortal DF-1 CEF cells.

\section{Background}

Normal (primary) cultured cells derived from living tissue exhibit a limited life span reaching replicative senescence in a non-dividing state [1]. Each cell division results in the generation and accumulation of various cellular genetic alterations, such as telomere shortening caused by the inability of DNA polymerases to fully replicate the ends of linear chromosomes [2,3]. This inability to overcome these alterations ultimately leads to cellular aging. Most cells are unable to overcome senescence unless key tumor suppressor pathways are first altered. Thus, cellular immortalization has been achieved by genetic alterations which bypass the stages leading to cellular senescence.

\footnotetext{
* Correspondence: bkong@uark.edu

${ }^{1}$ Department of Poultry Science, Center of Excellence for Poultry Science,

University of Arkansas, Fayetteville, Arkansas 72701, USA

Full list of author information is available at the end of the article
}

Spontaneous immortalization is a rare event in human and avian cells, but occurs much more frequently in rodent cells [4]. Unlike virally or chemically induced tumor cell lines, spontaneously induced, non-transformed cell lines lacking endogenous and exogenous viral genomes are much more useful for studying the conversion to an immortal state and to evaluate the effects of viral infection. Traditionally, in the absence of a suitable avian cell line, primary chicken embryo fibroblasts (CEF) have been used in virology and vaccine production, although a major disadvantage is the fluctuation of virus titers from lot to lot. Thus, there are advantages to using a spontaneously immortalized nontransformed cell line for vaccine production, which provides an unlimited supply of identical cells.

The immortal DF-1 CEF cell line was established spontaneously from Line 0 (endogenous-virus negative; [5]) embryos and has been widely used for the
C Biomed Central

() 2011 Kong et al; licensee BioMed Central Ltd. This is an Open Access article distributed under the terms of the Creative Commons Attribution License (http://creativecommons.org/licenses/by/2.0), which permits unrestricted use, distribution, and reproduction in any medium, provided the original work is properly cited. 
propagation of various avian viruses, including avian sarcoma leukosis virus [6,7], avian leukosis virus [8], Marek's disease virus [9], avian influenza virus [10,11], infectious bursal disease virus [12], and avian metapneumovirus $[13,14]$. The non-transformed DF-1 CEF cell line has been continuously grown in culture for more than 300 passages and does not harbor any known endogenous viruses $[7,15]$. DF-1 cells have enhanced growth potential compared to their primary CEF counterparts $[6,16]$. The morphology of DF-1 cells is that of a typical spindle-shaped fibroblast, but is much smaller than its primary CEF counterpart (Figure 1; [17]).

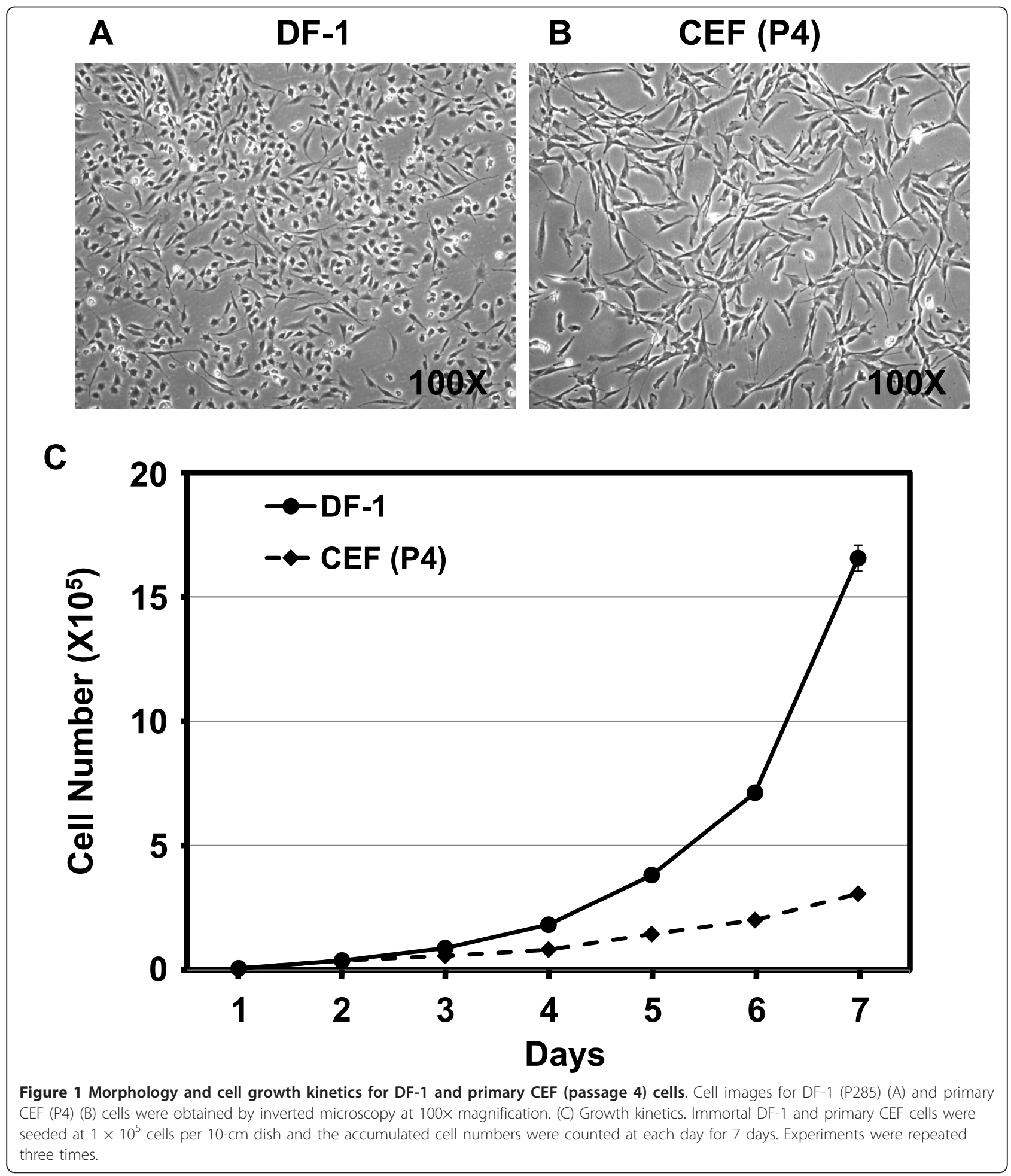


Various genetic, biochemical, and physiological characteristics of the DF-1 cell line have been reported. At the chromosomal level, DF-1 cells display different ploidy lineages and chromosomal rearrangements by maintaining a complex derivative karyotype which may be caused by chromosome fusions in homozygous and heterozygous conditions. In addition the DF-1 cells contain a greater amount of telomeric sequence repeats per genome compared to normal chicken cells and to a telomerase positive transformed lymphoma cell line [18]. Chromosome rearrangements and different ploidy thus may influence structural or dosagerelated alterations in gene expression. Indeed, DF-1 cells retain various genetic alterations of down-regulated p53 function, an up-regulated pRB (retinoblastoma protein) and E2F1 pathway, and elongated telomere length, which are commonly found in immortalized cells [19]. Compared to the parent line of primary CEF cells, DF-1 cells were shown to transcriptionally increase mitochondrial encoding gene expression and elevated mitochondrial respiratory functions, which supports its rapidly dividing cellular characteristics [16]. Moreover, cellular antioxidant genes, such as manganese containing superoxide dismutase (MnSOD or SOD2), copper-zinc containing SOD (CuZnSOD or SOD1), and catalase were deregulated transcriptionally and functionally in the DF-1 cell line. These deregulated antioxidant functions may be considered to be responsible for hypersensitivity to oxidative stress shown in DF-1 cells [20-22].

The DF-1 CEF cell line is a biologically important spontaneously immortalized cell line that has been utilized by great number of research groups for a host of research topics. Due to the diverse utility and the potentially unique genetic characteristics, the DF-1 cell line (along with several other chicken cell lines and chicken breeds) will be subjected to whole genome sequencing within the year (personal communication Jerry Dodgson, Michigan State University).

Biologic, virologic and important genetic alterations in immortal DF-1 CEF cells have been reported, however there are no reports concerning genome-wide gene expression profiling of the DF-1 cells to our knowledge. Thus, the major goal of this study was to conduct global gene expression analysis to profile differentially expressed genes in DF-1 CEF cells compared to their primary CEF counterpart using a $44 \mathrm{~K}$ chicken oligo microarray. The results indicate that DF-1 cells retain cellular characteristics of enhanced cell cycle progression and proliferation, down-regulated cell death pathways, hyperactive mitochondrial functions, and altered cellular morphogenesis.

\section{Results and Discussion}

Morphology and growth characteristics of DF-1 CEF cells

Immortal DF-1 CEF cells have been growing continuously in culture for a number of years. DF-1 cells at passage 285 morphologically showed typical characteristics of fibroblast cells, but are clearly smaller in size especially regarding cellular projections compared to primary passage 4 CEF cells (Figure 1A and 1B). Growth rates of DF-1 cells showed between 1.0 to 1.2 population doublings per day (PD/d) compared to $0.6-0.8 \mathrm{PD} / \mathrm{d}$ of primary CEF cell counterpart (Figure $1 \mathrm{C}$ ).

\section{Gene expression profile of immortal DF-1 CEF cells}

To find transcriptional alterations in DF-1 cells, genomewide expression profiling was conducted using RNA from primary and immortal DF-1 CEF samples. Although the primary CEF counterpart cells used in this study (SPF embryo origin) were not the original embryonic cells used for the establishment of DF-1 cells [from Line 0 (endogenous-virus negative) embryo origin], comparison of transcriptional alterations by microarray analysis was conducted to understand cellular characteristics of immortal- and rapidly growing DF-1 CEF cells compared to early passage of primary CEF cells having limited lifespan and a relatively slow proliferation rate. Of the $44 \mathrm{~K}$ probes used in the microarray analysis, a total of 3876 differentially expressed genes were identified in DF-1 CEF cells with a 2 fold level cutoff that included 1706 upregulated and 2170 down-regulated genes (Additional file 1 ). To validate the microarray results, 21 randomly chosen genes from the 3876 differential expression list were subjected to qPCR along with the GAPDH loading control gene. Results indicated that increased or decreased expression levels for all genes tested were well-matched in assays between microarray and qPCR analysis (Table 1). When 3876 differentially expressed probes were analyzed using Ingenuity Pathways Analysis (IPA, Ingenuity ${ }^{\circledR}$ Systems, http://www.ingenuity.com), 902 were classified as functionally known genes (Additional file 2). A list of the 10 most up- and down-regulated differentially expressed genes in the DF-1 cells are provided in Table 2.

The 10 up- and down-regulated genes in DF-1 cells exhibiting the greatest differential expression

The 10 most up-regulated genes (Table 3) are related to functions of cell cycle and proliferation, intracellular trafficking, cytoskeletal arrangement, and host-defense mechanisms against pathogenic infections. In contrast, the 10 most down-regulated genes in DF-1 cells (Table 3) are associated with cell cycle arrest and apoptosis, homeostasis, cell shape and movement, cellular respiration, and organ development. Of these, the up-regulation of 
Table 1 Comparison of fold changes between microarray and $\mathrm{qPCR}$

\begin{tabular}{cccc}
\hline Accession No. & Gene Symbol & Microarray & qPCR \\
\hline AB109635 & HMGCR & -1.03 & -0.81 \\
AB196971 & APCDD1 & 4.75 & 7.96 \\
AF505881 & SCX & -3.27 & -1.94 \\
AJ131110 & TWIST2 & 4.61 & 6.77 \\
BU279212 & CBLN2 & 7.84 & 8.64 \\
BX929635 & NDP & -4.26 & -1.64 \\
BX931599 & VIPR2 & -2.90 & -11.34 \\
BX932694 & MPZL2 & 5.51 & 4.16 \\
BX933478 & MXRA5 & -2.69 & -7.97 \\
BX933888 & C1QTNF3 & -2.53 & -2.28 \\
BX935456 & EGLN3 & -3.04 & -4.48 \\
BX936211 & TMEM116 & 4.26 & 5.94 \\
CK611983 & CSTA & 4.49 & 7.92 \\
CR385566 & CLEC3B & -4.46 & -3.58 \\
D87992 & ANPEP & -4.25 & -6.29 \\
M60853 & THBS2 & -5.15 & -5.28 \\
M64990 & PTGS2 & -6.78 & -10.36 \\
M80584 & LUM & -3.14 & -4.59 \\
M87294 & NPY & -3.73 & -7.15 \\
X87609 & FST & -4.12 & -10.04 \\
\hline
\end{tabular}

The gene expression levels of 20 genes from microarray analysis were confirmed by $\mathrm{qPCR}$. The expression levels were presented by fold changes values in microarray analysis, while, for $\mathrm{qPCR}$, the values were calculated by 2 $\triangle \Delta C T$ method, which were comparable to fold changes in the microarray. All values are mean values determined by the calculations from three replicate assays.

OSGIN1, COLEC10, and SOCS1 and the down-regulation of ST3GAL1, PTGS2, and CCK in DF-1 cells appears initially to be incongruous with the rapid growth potential that is characteristic of these cells. Although the connections to cellular phenotypes from mRNA expression data may not be as strong as expected due to the potential lack of correlation between mRNA expression and protein abundance (which have been reported previously in both prokaryotes and eukaryotes [23-27]), the highly and dramatically differentially expressed genes may represent correlations between transcripts, protein abundance and the differential abundance of proteins in two different cell types, respectively. Thus, further study is needed to reveal the functional roles of these genes in DF-1 cells.

\section{Functional groups of differentially expressed genes}

The IPA program generated bioinformatics data sets including functional groups (gene ontology; GO) and gene networks for differentially expressed genes in immortal DF-1 CEF cells. Of the biologically functional groups for 904 differentially expressed genes, the top 15 functional groups are displayed in Figure 2. The greatest numbers of genes are mainly categorized into functionalities of cellular growth and proliferation, cell cycle, cellular movement, cancer, genetic disorders, and cell death, suggesting that the transcriptional alterations that occurred in DF-1 cells are closely related and likely responsible for a great deal of the rapid growth and phenotypic changes in this cell line.

\section{Gene networks}

Gene network analysis, which represents the intermolecular connections among interacting genes based on functional knowledge inputs, was performed on the differentially expressed genes using the IPA program. Of various assay settings, the simplest settings (35 focus molecules and 10 networks) were employed to analyze molecular gene networks in order to facilitate and summarize the connections among the larger number of differentially expressed genes (Table 4 and Figures 3, 4, 5, $6,7)$. A discussion of the top five gene networks is provided below and gene information for focus molecules in each network was listed in Additional file 3.

Network \#1 is closely associated with the E2F1 and BRCA1 (breast cancer 1, early onset) pathways in cell cycle regulation (Figure 3). Likewise, the top functions related to network \#1 are cell cycle regulation, DNA replication, recombination, repair, and cellular assembly and organization. Up-regulation of E2F1 in immortal CEF cell lines including DF-1, heart derived- and breast derived CEF cells was reported previously together with the genetic alterations for cell cycle regulatory genes, such as the down-regulation of p53, MDM2, p21CIP as well as the upregulation of $\mathrm{pRB}$, the cyclins (except cyclin D2), c-Fos, c-Jun, and Bcl2 [19]. These cell cycle regulatory genes showed a similar expression pattern in the full differential expression list of 3876 genes. However, with the exception of E2F1, these genes were not recognized by the IPA program. This difference might be the result of the IPA program, which focuses mainly on mammalian gene information and pathways, and does not fully cover chicken gene annotations. It suggests that comparing and contrasting data of both the IPA differential expression list and the manufacturer's differential expression list is more helpful for comprehensively understanding the differential expression datasets.

E2F1 is a member of the E2F family of transcription factors that play a crucial role in controlling the cell cycle by association with the tumor suppressor protein, pRB (retinoblastoma protein). E2F transcription factors are the effectors of the G1/S transition of the cell cycle. When bound to DNA, E2F transcription factors exist either as free E2F/DP (E2F dimerization partner) heterodimers, or are associated in larger complexes containing members of the retinoblastoma family (pRB, p107, p130) and members of the cyclin/CDK protein families. CDKs are comprised of a family of serine/threonine protein 
Table 2 The 10 most up- and down-regulated genes in DF-1 cells as determined by Ingenuity Pathway Analysis software

\begin{tabular}{|c|c|c|c|c|}
\hline \multicolumn{5}{|c|}{ The 10 most up-regulated genes } \\
\hline ID & Symbol & Entrez Gene Name & Log Ratio & p-value \\
\hline$\overline{A B 196971}$ & APCDD1 & adenomatosis polyposis coli down-regulated 1 & 4.75 & $4.68 \times 10^{-8}$ \\
\hline AJ131110 & TWIST2 & twist homolog 2 (Drosophila) & 4.61 & $3.93 \times 10^{-9}$ \\
\hline BX936211 & TMEM116 & transmembrane protein 116 & 4.26 & $9.58 \times 10^{-10}$ \\
\hline S64689 & MYH6 & myosin, heavy chain 6 , cardiac muscle, alpha & 3.52 & $4.92 \times 10^{-6}$ \\
\hline AJ851540 & CARD11 & caspase recruitment domain family, member 11 & 3.51 & $1.66 \times 10^{-8}$ \\
\hline BX932923 & PLEK2 & pleckstrin 2 & 3.47 & $2.63 \times 10^{-8}$ \\
\hline CR523499 & OSGIN1 & oxidative stress induced growth inhibitor 1 & 3.43 & $5.04 \times 10^{-9}$ \\
\hline DQ129668 & COLEC10 & collectin sub-family member 10 (C-type lectin) & 3.19 & $1.81 \times 10^{-7}$ \\
\hline BX933215 & SOCS1 & suppressor of cytokine signaling 1 & 3.05 & $3.63 \times 10^{-7}$ \\
\hline CR407099 & VPS13B & vacuolar protein sorting 13 homolog B (yeast) & 3.03 & $3.44 \times 10^{-6}$ \\
\hline \multicolumn{5}{|c|}{ The 10 most down-regulated genes } \\
\hline ID & Symbol & Entrez Gene Name & Log Ratio & p-value \\
\hline X59284 & NOV & nephroblastoma overexpressed gene & -8.40 & $3.11 \times 10^{-9}$ \\
\hline AJ719388 & SLC25A4 & solute carrier family 25 (mitochondrial carrier; adenine nucleotide translocator), member 4 & -7.69 & $1.22 \times 10^{-10}$ \\
\hline Y138247 & CDKN2B & cyclin-dependent kinase inhibitor 2B (p15, inhibits CDK4) & -7.68 & $2.75 \times 10^{-10}$ \\
\hline X80503 & ST3GAL1 & ST3 beta-galactoside alpha-2,3-sialyltransferase 1 & -7.26 & $4.67 \times 10^{-9}$ \\
\hline M64990 & PTGS2 & prostaglandin-endoperoxide synthase 2 (prostaglandin $\mathrm{G} / \mathrm{H}$ synthase and cyclooxygenase) & -6.78 & $1.11 \times 10^{-10}$ \\
\hline X935556 & CTHRC1 & collagen triple helix repeat containing 1 & -6.78 & $3.20 \times 10^{-8}$ \\
\hline M68514 & EPHA3 & ephrin receptor A3 & -6.73 & $5.89 \times 10^{-9}$ \\
\hline AJ719946 & MANSC1 & MANSC domain containing 1 & -6.65 & $5.66 \times 10^{-8}$ \\
\hline AJ251273 & CCK & cholecystokinin & -6.63 & $1.27 \times 10-11$ \\
\hline Y049705 & MAB21L1 & mab-21-like 1 (C. elegans) & -6.44 & $2.26 \times 10^{-10}$ \\
\hline
\end{tabular}

Fold change (FC) values were indicated by log2. The highly differentially expressed genes were sorted. All genes were matched and verified with UniGene function of NCBI database.

kinases that phosphorylate a number of substrates mainly implicated in cell cycle progression and transcription. Association of E2Fs with the pRB family facilitates active repression through recruitment of histone deacetylases [28]. Genes directly interacting with E2F1 include factors for DNA replication [e.g. DNA replication factor C (RFC) 2, 3, 4] [29], DNA recombination and repair of double strand breaks (e.g. RAD 17, 51, 52, 54B, 54L and FEN1; flap structure-specific endonuclease 1) $[30,31]$, and maintenance of genomic stability (e.g. BRCA1). BRCA1 is a nuclear phosphoprotein that makes a super complex, denoted as Basc (BRCA1 associated genome surveillance complex), which is associated with tumor suppressors and DNA damage repair proteins such as nibrin (NBN) [32]. In network \#1, BRCA1 binding proteins, MED17 (mediator complex subunit 17), which is a transcription co-factor with TFIID, RAD51 and BARD1 (BRCA1 associated RING domain 1) are also up-regulated, suggesting that BRCA1 transcriptional activity may be increased in DF-1 CEF cells. Also DNA polymerases including POLD3 (polymerase-DNA directed-delta 3 subunit) and PRIM2 (primase 2) were up-regulated in network \#1. The upregulation of all of these genes and complexes make 'teleological sense' with regard to the rapid growth characteristics of DF-1 CEF cells. In addition, ATPase related factors including ATPB1 (ATPase, $\mathrm{Na}+/ \mathrm{K}+$ transporting), ABCC6 (ATP binding cassette, sub-family 6), ATP5S (ATP synthase, $\mathrm{H}+$ transporting, mitochondrial complex), and KATNA1 (ketanin p60- ATPase containing subunit A1) were also up-regulated and consistent with the previous report of the hyperactivation of mitochondrial functions and up-regulation of mitochondrial gene expression [16]. These results suggest that DF-1 CEF cells may contain cellular systemic alterations to accelerate metabolic energy expenditure. Moreover, cellular proliferation inhibitory factors or apoptosis inducing factors, such as MT2A (metallothionein 2A) and ARHCEF4 (Rho guanine nucleotide exchange factor 4) were down-regulated in DF-1 CEF cells $[33,34]$ that again would contribute to the phenotypic expression of rapid growth rate and resistance to senescence that is characteristic of DF-1 cells.

Similar to network \#1, the top functions of network \#2 include DNA replication, recombination and repair, cell cycle, and cellular assembly and organization (Figure 4). Central in this network are CASP3 (caspase 3), molecules inducing apoptosis including SFRP1 (secreted 
Table 3 Biological functions of the 10 most up- and down-regulated genes

\begin{tabular}{|c|c|}
\hline \multicolumn{2}{|c|}{ Up-regulation } \\
\hline Symbol & Functions \\
\hline APCDD1 & $\begin{array}{l}\text { - Directly regulated by the } \beta \text {-catenin/T-cell factor signaling complex } \\
\text { - Increased expression in colon cancer cells and potential roles in colorectal tumorigenesis [75]. }\end{array}$ \\
\hline TWIST2 & $\begin{array}{l}\text { - A basic helix-loop-helix transcription factor } \\
\text { - Inhibits both p21WAF1/Cip1 (cyclin dependent kinase inhibitor) and muscle creatinine kinase (MCK) } \\
\text { - Functional association with cellular growth arrest and myogenesis specific expression [76] } \\
\text { - Possibly alternate regulatory factor involved in the lowered expression of p21WAF1/Cip1 in DF-1 cells that in turn would support } \\
\text { the faster growth rate that is characteristic of the DF-1 cell line [19]. }\end{array}$ \\
\hline TMEM116 & $\begin{array}{l}\text { - Unknown functions } \\
\text { - A single nucleotide polymorphisms are associated with insulin-dependent diabetes mellitus in human [77] }\end{array}$ \\
\hline MYH6 & $\begin{array}{l}\text { - Alpha subunit of cardiac muscle myosin } \\
\text { - Association cytoskeletal or muscle architecture [78] } \\
\text { - Taken together with MYL10 (myosin light chain 10), which is up-regulated in DF-1 cells (Additional file 2), mutations are } \\
\text { associated with cardiomyopathy or cardiac hypertrophy [79] }\end{array}$ \\
\hline$\overline{\text { CARD11 }}$ & $\begin{array}{l}\text { - Known as Carma1 belonging to the membrane-associated guanylate kinase (MAGUK) family that is essential in antigen receptor- } \\
\text { induced nuclear factor } \kappa \mathrm{B}(\mathrm{NF}-\kappa \mathrm{B}) \text { activity in T-cell activation [80] }\end{array}$ \\
\hline PLEK2 & $\begin{array}{l}\text { - A membrane associated protein containing PH (pleckstrin homology) motifs that bind polyphosphoinositides } \\
\text { - Roles in orchestrating cytoskeletal structural arrangement [81] }\end{array}$ \\
\hline OSGIN1 & $\begin{array}{l}\text { - Known as BDGI [BMSC (bone marrow stromal cell)- derived growth inhibitor] or OKL38 (pregnancy-induced growth inhibitor) } \\
\text { - Suppression of the growth of MCF7 human breast cancer cell by inducing cell cycle arrest and apoptosis when OSGIN1 was } \\
\text { ectopically expressed exogenously [82] }\end{array}$ \\
\hline COLEC10 & $\begin{array}{l}\text { - Known as CLL1 (colletin liver 1), a member of the C-lectin family } \\
\text { - Roles in initial host defense by binding sugars on the cell surface of microorganisms through their carbohydrate recognition } \\
\text { domain [83]. } \\
\text { - Essential host factor for early replication of influenza virus in cultured cells revealed by genome wide siRNA screening [84] } \\
\text { - Its mRNA down-regulated in human liver hepatocellular carcinoma by microarray analysis [85]. }\end{array}$ \\
\hline SOCS1 & $\begin{array}{l}\text { - Suppression of many cytokine-signaling pathways by inhibiting JAK tyrosine kinase activity and functions as antioncogene by } \\
\text { antagonizing tumor cell growth [86]. }\end{array}$ \\
\hline VPS13B & $\begin{array}{l}\text { - Known as } \mathrm{COH} 1 \text {, involved in intracellular vesicle-mediated sorting and transport of proteins and with Cohen syndrome, which is } \\
\text { an autosomal recessive disorder in human caused by the genetic mutation in } \mathrm{COH} 1 \text { gene [87]. }\end{array}$ \\
\hline \multicolumn{2}{|c|}{$\begin{array}{l}\text { Down- } \\
\text { regulation }\end{array}$} \\
\hline Symbol & Functions \\
\hline NOV & $\begin{array}{l}\text { - Known as CCN3, a member of the secreting insulin like growth factor binding protein family with antiprolifereative effects on } \\
\text { tumor cells }[88,89] \text {. }\end{array}$ \\
\hline SLC25A4 & $\begin{array}{l}\text { - Known as ANT1 (adenine nucleotide translocator 1) } \\
\text { - Localized to the inner mitochondrial membrane, exchanges cytosolic ADP for mitochondrial ATP, and induces apoptosis by the } \\
\text { mitochondrial recruitment of NF- } \kappa \text { B [90]. } \\
\text { - Decrease in ANT1 might play in a role in immortalization characteristics by suppressing the induction of apoptosis in DF-1 cells. }\end{array}$ \\
\hline CDKN2B & $\begin{array}{l}\text { - Known as p15INK4B, CDK4/6 inhibitor } \\
\text { - Arrest cell cycle and induce cellular senescence [91]. } \\
\text { - The down-regulation in DF-1 cells caused by hyper-methylation } \\
\text { - Functional roles both in the progression of cellular senescence and in brain development were reported previously [92,93]. }\end{array}$ \\
\hline ST3GAL1 & $\begin{array}{l}\text { - Type II membrane protein that catalyzes the transfer of sialic acid from CMP-sialic acid to galactose-containing substrates } \\
\text { - A knock-out mutation increases apoptosis of mouse T lymphocytes expressing the CD8 complex, indicating a homeostatic } \\
\text { function of STGAL1 in T lymphocyte [94]. }\end{array}$ \\
\hline PTGS2 & $\begin{array}{l}\text { - Known as COX2 (cyclooxygenase 2), the key rate-limiting enzyme in prostaglandin biosynthesis with both dioxygenase and } \\
\text { peroxidase activity } \\
\text { - Inhibition of apoptosis by suppressing caspase pathways and the increase of survival mechanisms through Akt activation [95]. }\end{array}$ \\
\hline CTHRC1 & - A secreted protein in injured and diseases arteries that inhibits collagen expression and promotes cell migration [96]. \\
\hline EPHA3 & $\begin{array}{l}\text { - A unique member of the receptor tyrosine kinase family } \\
\text { - Roles in regulating cell shape and cell movement [97]. }\end{array}$ \\
\hline MANSC1 & $\begin{array}{l}\text { - A protein containing a MANSC (motif at N terminus with seven cysteines) domain that presents certain membrane- and } \\
\text { extracellular proteins such as LPR11 (low-density lipoprotein receptor-related protein 11) and HAl1 (hepatocyte growth factor } \\
\text { activator inhibitor 1) [98] } \\
\text { - Unknown the functions }\end{array}$ \\
\hline
\end{tabular}




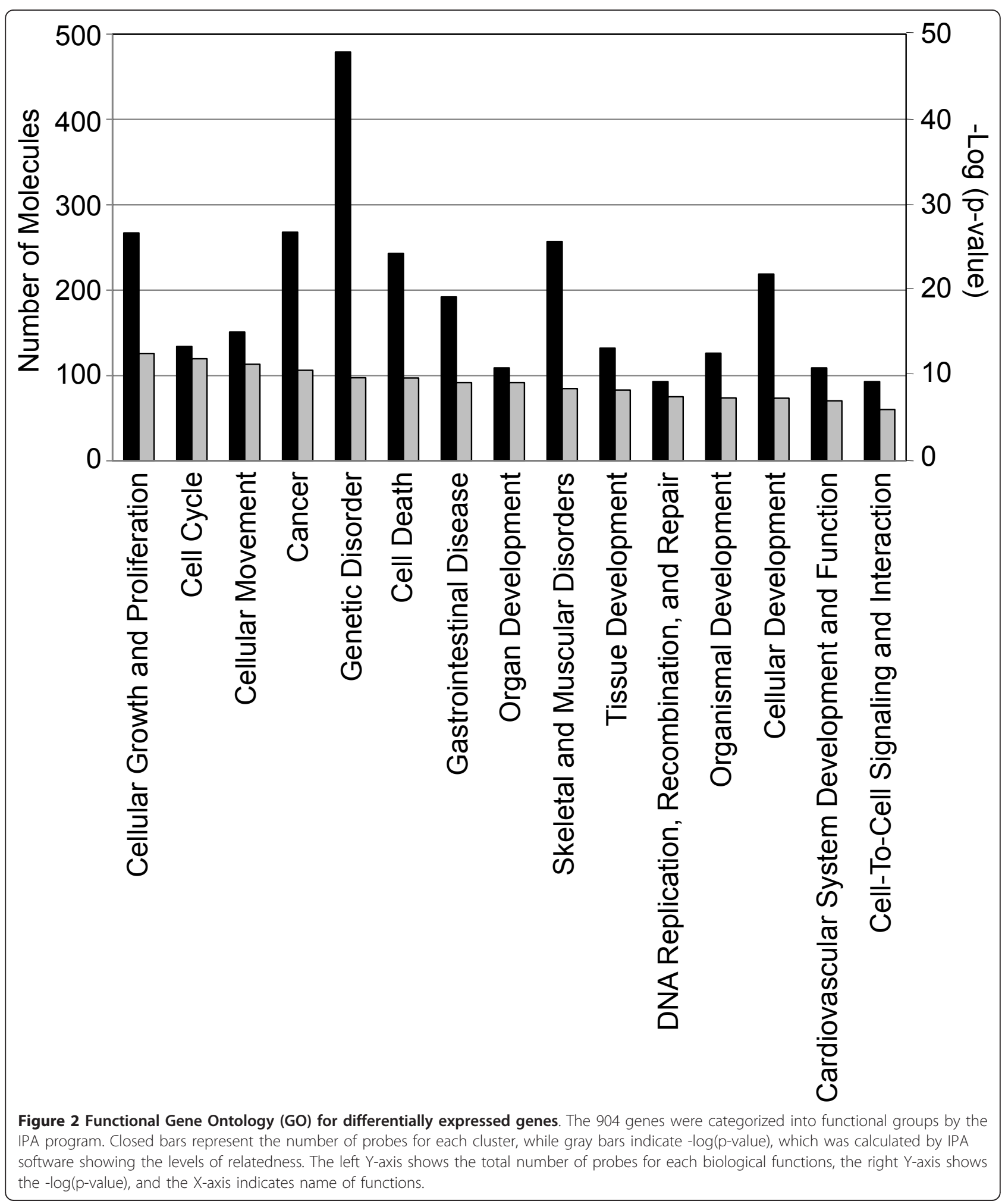


Table 4 Associated network functions

\begin{tabular}{ccccc}
\hline ID & & Associated network functions & Score & Focus Molecules \\
\hline 1 & Cell Cycle, DNA Replication, Recombination, and Repair, Cellular Assembly and Organization & 33 & 28 \\
\hline 2 & DNA Replication, Recombination, and Repair, Cell Cycle, Cellular Assembly and Organization & 31 & 27 \\
\hline 3 & Cancer, Cardiovascular System Development and Function, Organismal Development & 30 & 26 \\
\hline 4 & Molecular Transport, Tissue Morphology, Cell Cycle & 29 & 27 \\
\hline 5 & Cellular Assembly and Organization, Developmental Disorder, Skeletal and Muscular Disorders & 28 & 25
\end{tabular}

Functions associated with 10 networks are listed. Score means the number of network eligible molecules out of differentially expressed genes.

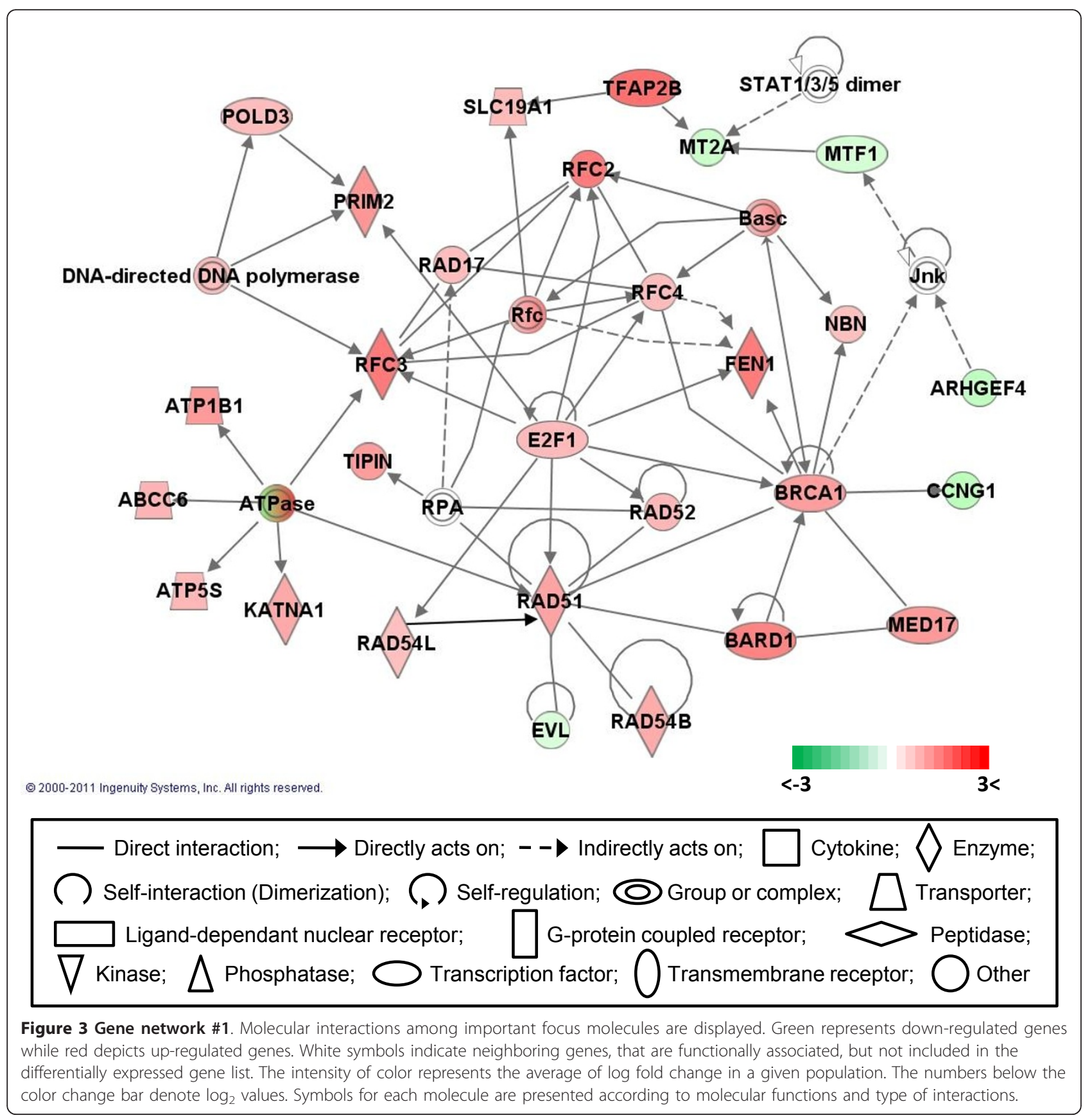




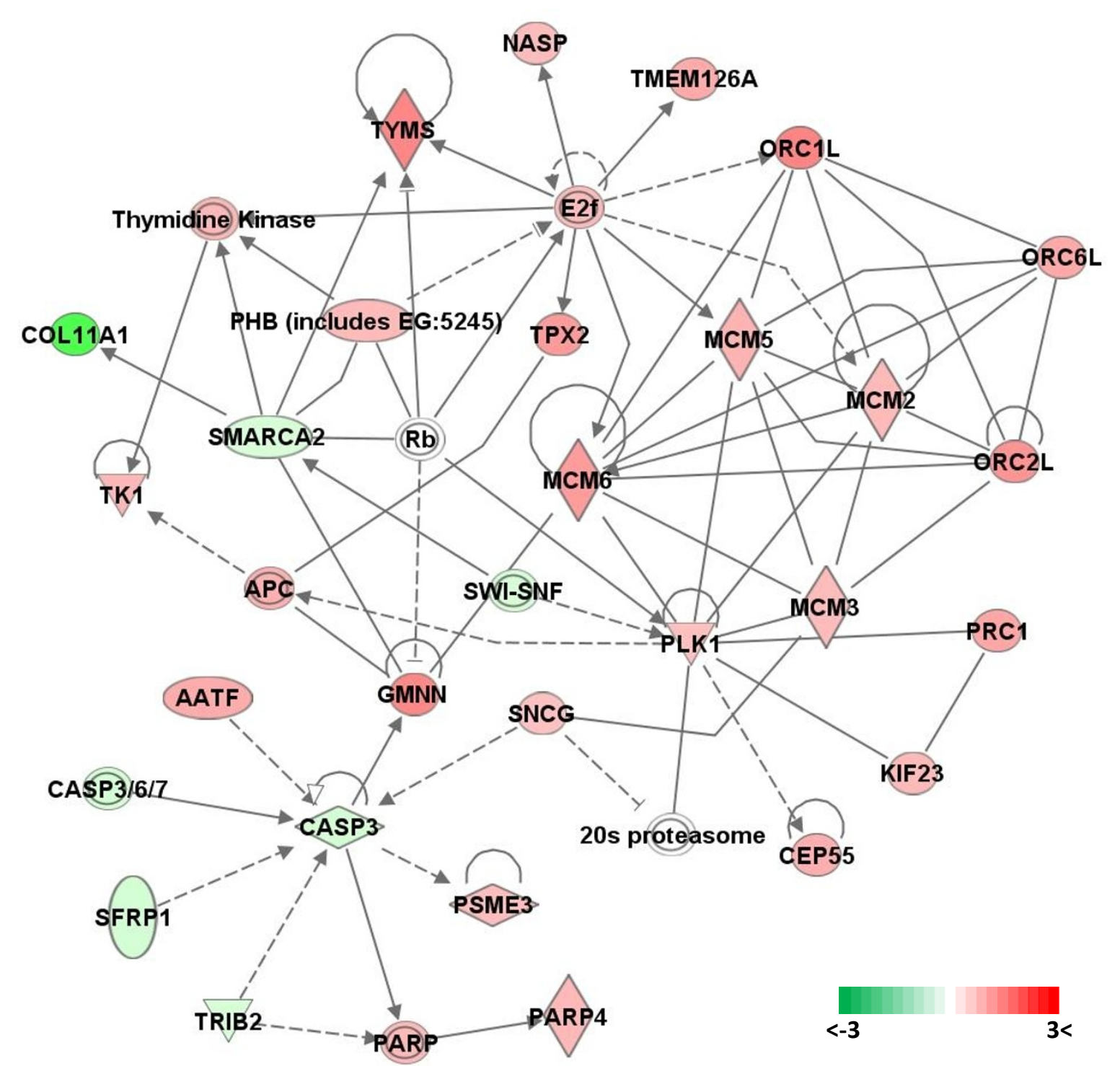

๑2 2000-2011 Ingenuity Systems, Inc. All rights reserved.

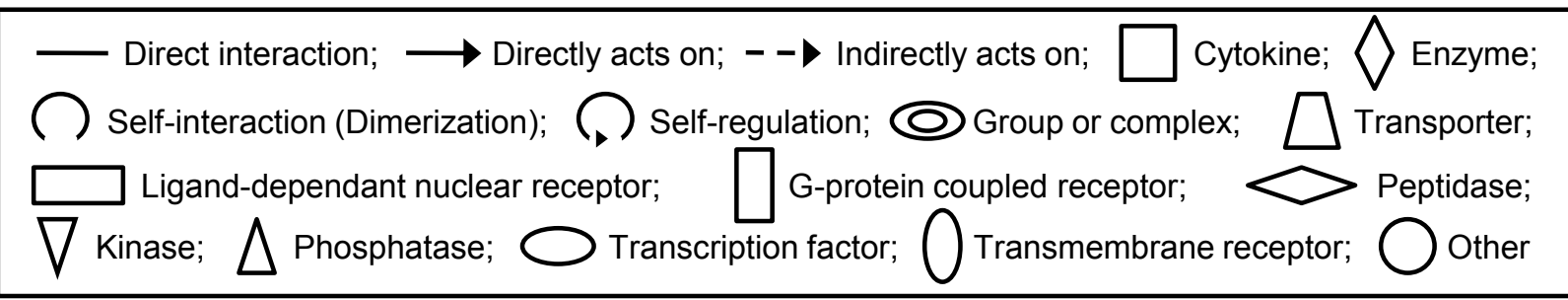

Figure $\mathbf{4}$ Gene network \#2. Molecular interaction, symbols, and color schemes are the same as the description in Figure 3.

frizzled-related protein 1) and TRIB2 (tribbles homolog 2) which were all down-regulated. The Caspase family are cysteine-aspartic acid proteases which play major roles in the execution phase of cell apoptosis $[35,36]$.
SFRP1 acts as soluble modulators of Wnt (hybrid of wingless and integration 1) signaling and suppresses tumor cell growth through the Wnt signaling pathway [37]. 'However, functional roles of SFRP1 in apoptosis 
related to CASP3 expression depends on the cell type [38]. TRIB2, which is an atypical protein serine-threonine kinase, is known to coordinate cell proliferation, migration, and morphogenesis during the development of Drosophila and Xenopus embryos and is involved in apoptosis in mammalian cell lines [39]. Also, AATF (apoptosis antagonizing transcription factor), which suppresses apoptosis induced by oxidation [40], was upregulated in DF-1 CEF cells. These results generally suggest cell death pathways are suppressed in DF-1 cells that, in turn, support the immortal and hyperproliferative capability of DF-1 cells. Moreover, in human, GMNN (geminin), which negatively regulates DNA replication 'licensing' (the one time initiation of replication in a single cell cycle) by preventing the formation of the pre-replicative complex on origins of replication through the physical association with the 'licensing' factor Cdt1 [41,42], was cleaved by CASP3 during apoptosis [43]. The suppression of GMNN by siRNA knockdown can selectively kill cancer cells [44] and GMNN directly interacts (binds to) MCM6 (minichromosome maintenance complex component 6), which is an essential factor for the initiation of eukaryotic genome replication [45] in addition to other MCM molecules including MCM2, 3, $5[46,47]$ in network \#2, indicating that GMNN may have an important role in expediting DNA replication. Other E2F-1 transcription targets including TYMS (thymidylate synthetase), NASP (nuclear autoantigenic sperm protein-histone binding), ORC1L (origin recognition complex-subunit 1-like), and TPX2 (microtubule-associated, homolog) are up-regulated in DF-1 cells $[48,49]$. Furthermore, direct interactions among highly expressed ORC1L, ORC6L, ORC2L and MCM families, which are components protein complex essential for the initiation of the DNA replication in eukaryotic cells, were found in network \#2 [50,51]. Up-regulation of PLK1 (polo like kinase1), KIF23 (kinesin family member 23), and PRC1 (protein regulator of cytokinesis 1) through the direct interactions among those molecules may facilitate mitosis and cytokinesis at the late phase of the cell cycle in DF-1 cells [52-54].

Molecules in network \#3 are involved in cancer, cardiovascular system development and function, and organismal development (Figure 5). Glutathione peroxidases (GPX7 and 8) and glutathione S transferases (GST-A4, -T1, and -Z1) were downregulated except for GST-O1. This result is consistent with the previous report of higher levels of reactive oxygen species that were produced and accumulated in DF-1 CEF cells possibly due to higher respiratory rates, higher superoxide dismutase and lowered catalase activity, resulting in hypersensitivity to oxidative damage [22]. Taken together, lower levels of GPXs and GSTs may be responsible for higher levels of intracellular oxidative stress and susceptibility to oxidative damage in DF-1 cells. In contrast to the down-regulation of CASP3 in network \#2, initiator caspases (CASP) 2 and 8 were up-regulated in DF-1 cells implicating a more active induction of apoptosis when DF-1 cells encounter cell damage, such as oxidative stress or pathogenic infections. DF-1 cells have been utilized as an excellent substrate for the propagation of various viruses, since the cells support high virus titers and generate clear cytopathic effects, such as syncytium formation (nuclear aggregation during virus replication) $[6,7,9,10]$. Virus infections usually induce apoptosis during lytic propagation stages. Therefore, the up-regulation of apoptosis initiator caspases may play a role during virus infection in DF-1 cells. In addition, prion protein (PRRN) and its interacting proteins including NTM (neurotrimin), LSAMP (limbic system-associated membrane protein), and CLSTN1 (calsyntenin 1) were downregulated in DF-1 cells. Normally, functional cellular PRRN is known to promote G1/S cell cycle processing, and has resulted in increasing proliferation of human gastric cancer cells [55], but the higher proliferation capability of DF-1 cells may not be stimulated by prions and their interacting molecules.

Network \#4 contains molecules involved in molecular transport, tissue morphology, and the cell cycle (Figure 6). In network \#4, three subunits of the NDC (nuclear division cycle) 80 complex, which is a homolog of Yeast kinetochore complex component containing NDC80, (a. k. a. HEC1 in mammalian species), SPC (spindle pole component) 24, SPC25, and NUF2, and mediates attachment of chromosomes to microtubules, were differentially expressed showing up-regulation of NDC80 and SPC25 and down-regulation of NUF2. The NDC80 complex is evolutionarily conserved and contains four subunits SPC24, SPC25, NUF2 and NDC80. In budding yeast, the NDC80 complex plays a critical role in establishing the stable kinetochore-microtubule interactions required for chromosome segregation in mitosis $[56,57]$. Of the NDC80 subunits, chicken SPC24 has not been characterized to date. The unbalanced expression of the components in the NDC80 complex in DF-1 cells may lead unstable chromosome segregation, resulting in different ploidy and a complex derivative karyotype caused by chromosomal rearrangements during rapid proliferation cycles [18]. Several secreting proteins, including IL16 (interleukin 16), FGFBP1 (fibroblast growth factor binding protein 1), SERPINE2 (serpine peptidase inhibitor), VIP (vasoactive intestinal peptide), and NRG1 (neuregulin 1) are found in network \#4. VIP and NRG1 were up-regulated, while FGFBP1, IL16 and SERPINE2 were down-regulated. VIP is known to increase cyclin D1 expression and cell proliferation [58], and NRG1, which is a ligand for epidermal growth factor and its receptor, causes constitutive activation of several 


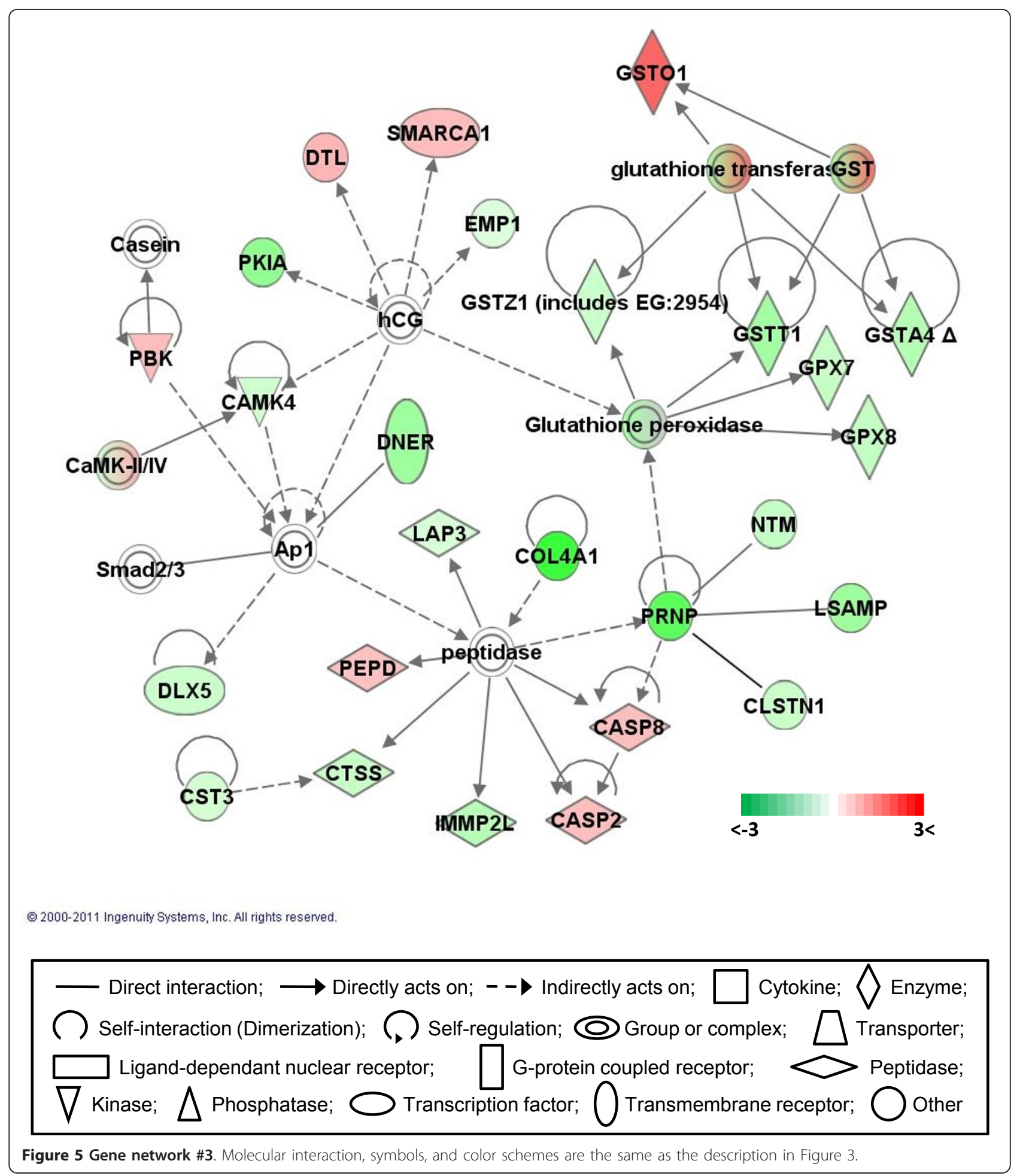

signaling pathways, such as the Erk1/2, Erk5, and Akt routes, which have been linked to cell proliferation [59]. SERPINE2, a.k.a thrombin inhibitor protease nexin 1, has negative effects on myofibroblastic cell growth by regulating PI3 kinase-Akt pathway [60]. The ectopic expression of the IL16 prodomain in tumor cell lines has triggered growth arrest and apoptosisis [61]. With the exception of FGFBP3, differentially expressed secreted proteins in DF-1 CEF cells were closely related to growth promoting activity. Factors involving tissue 


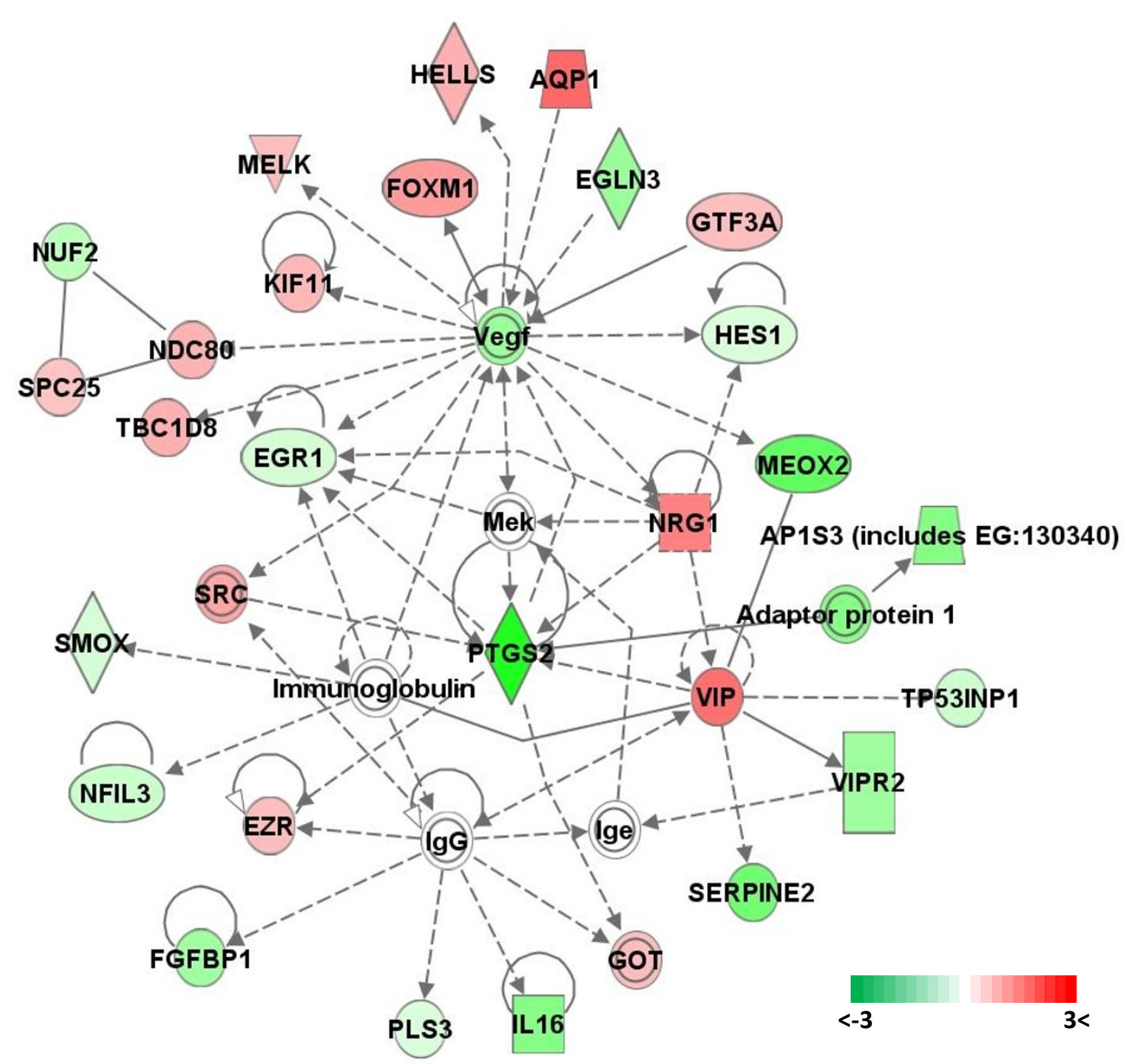

() 2000-2011 Ingenuity Systems, Inc. All rights reserved.

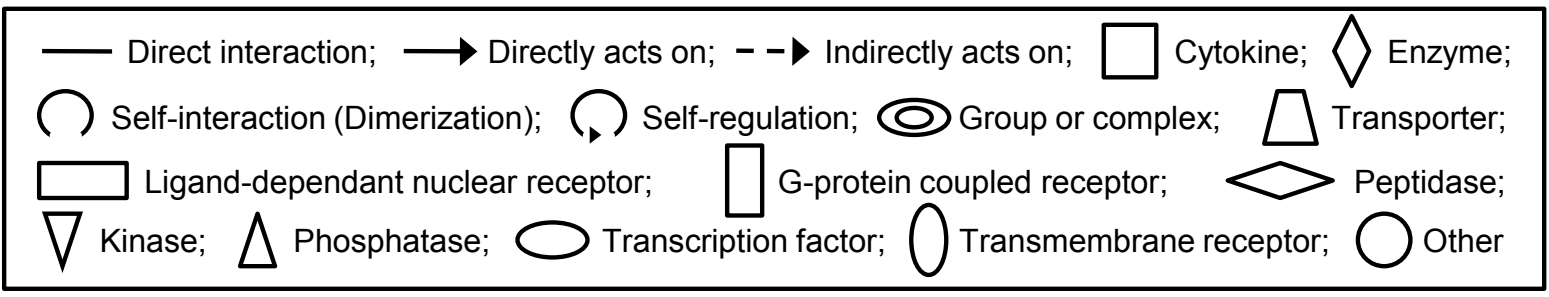

Figure 6 Gene network \#4. Molecular interaction, symbols, and color schemes are the same as the description in Figure 3.

morphology in network \#4 include EGLN3 (egl nine homolg 3), EGR1 (early growth response 1), FOXM1 (forkhead box M1), HES1 (hairy and enhancer of split 1, Drosophila), MEOX2 (mesenchyme homeobox 2), NFIL3 (nuclear factor, interleukin 3), NRG1, PTGS2 (prostaglandin-endoperoxide synthase 2), VIP, and
VIPR2 (VIP receptor 2). The specific functional roles of differentially expressed genes in the morphogenesis of DF-1 cells are being further investigated.

Finally, molecules in network \#5 are involved in the cellular assembly and organization, developmental disorders, and skeletal and muscular disorders (Figure 7). 


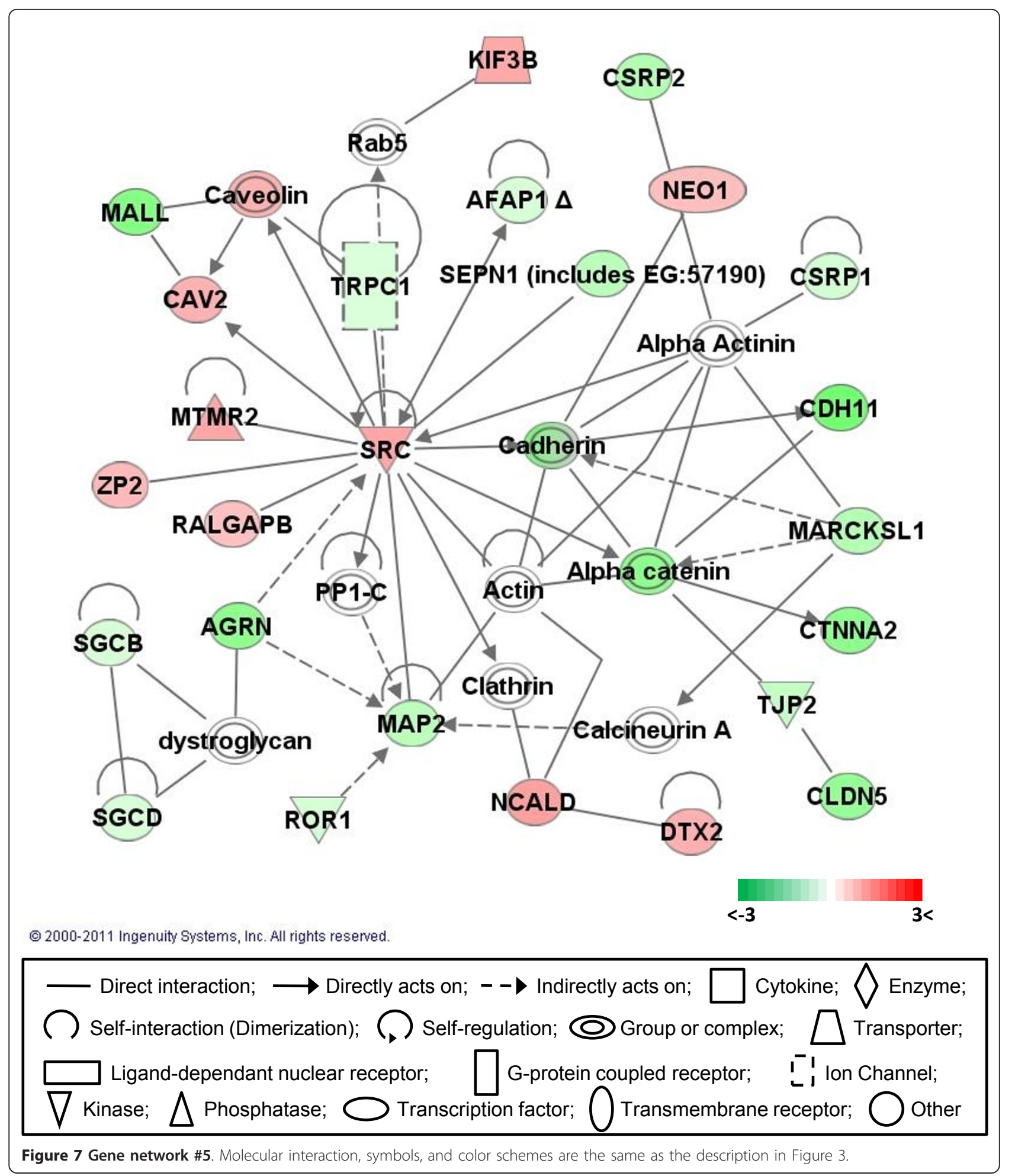

Network \#5 was mainly centered around up-regulated SRC (v-src homolog - avian) and down-regulated actin related factors. SRC, the cellular homolog of the Rous sarcoma virus $\mathrm{v}$-src, is a protooncogene and may play a role in cell growth in addition to embryonic development. SRC is a tyrosine kinase whose enzymatic activity is necessary to induce oncogenic transformation [62]. The SRC interactive molecules including CAV2 (caveolin 2; [63]), MTMR2 (myotubularin related protein 2; [64]), ZP2 (zona pellucida glycoprotein 2; [65]), 
RALGAPB (Ral GTPase activating protein-beta subunit; [65]), AFAP1 (actin filament associated protein 1;[66]), and TRPC1 (transient receptor potential cation channelsubfamily C; [67]) are phosphorylated by SRC and are considered to improve cellular proliferation, suggesting that differentially expressed SRC and SRC-interacting molecules may play important roles for the rapid proliferation of DF-1 cells. Cellular structural proteins such as actinin, cadherin, and catenin, and their interacting molecules including CSRP (cystein and glycine-rich protein) 1, CSRP2, CDH11 (cadherin 11), MARCKSL1 (MARCKS like 1; muscle LIM protein, MLP), CTNNA2 (catenin alpha 2), and TJP2 (tight junction protein 2) were down-regulated in DF-1 cells, suggesting that these factors may be involved in the distinct morphology of DF-1 cells compared to primary CEF cells. Factors involved in cellular assembly and organization in network \#5 include AGRN (agrin), MAP2 (microtubuleassociated protein 2), SGCB (sarcoglycan beta), SGCD (sarcoglycan delta), and SRC. Proteins functioning in skeletal and muscular disorders in network \#5 include CDH11, CSRP2, CTNNA2, MAP2, ROR1 (receptor tyrosine kinase like orphan receptor 1), SEPN1 (selenoprotein 1), SGCB, SGCD, and SRC and factors related to developmental disorder are MARCKSL1, SGCB, SGCD, SRC, and TRPC1. Specific roles of each of these factors need further investigation.

In summary, global gene expression analysis in this study provides insight into the entire genome-wide alterations in immortal DF-1 CEF cells. Bioinformatic analyses suggested that DF-1 cells are characterized by enhanced molecular mechanisms for cell cycle progression and proliferation, suppressing cell death pathways, altered cellular morphogenesis, and accelerated capacity for molecule transport. In addition to previously known potential genetic alterations, such as elongation of telomere length and deregulation of cell cycle regulatory factors including p53, E2F1, the CDKs, and cyclins, which could possibly allow DF-1 cells to become immortal, one of the new potential regulatory factors suggested in this study is the cellular SRC (c-SRC) molecule, which is a cellular counter part of viral SRC (v-SRC) oncoprotein found in Rous sarcoma virus. The c-SRC is generally known as a protooncogene involved in regulating cellular proliferation and the mutant version of c-SRC will induce transformation. Though it is not known whether the c-SRC gene in DF-1 cells is mutated or not, the increased expression of c-SRC in DF-1 CEF cells suggests a contribution to the immortalization of the cell by prolonged activation of growth signal and the anti-apoptotic activity. Indeed, we performed functional analysis using small interfering (siRNA) to target E2F1, BRCA1, and SRC, three highly up-regulated and potentially meaningful genes for the rapid growth of DF-1 cells. As shown in Additional file 4 A-D, siRNA against E2F1 (A) marginally reduced DF1 cell growth [2.16 fold increase in the number of cells at 3 day post transfection (dpt) compared to the number of cells at $1 \mathrm{dpt}$ ] compared to the negative control siRNA transfection (2.49 fold increase), siRNA against BRCA1 (B) and SRC (C) showed only 1.68- and 1.56 fold increases of DF-1 cell population at $3 \mathrm{dpt}$, respectively. The marginal effect of siE2F-1 may be due to a possible compensatory effect that other E2F family genes may have on cell proliferation such as shown by E2F3 in mouse fibroloblastic cells [68]. Knock-down approaches for BRCA1 and SRC showed more significant effects on growth inhibition in DF-1 cells, similar to the result of the positive control siRNA against beta-actin (D). Additional file 5 A shows the induction of CDKN2B (known as p15INK4B) by a demethylation chemical (5-aza-2'deoxycytidine). Additional file $5 \mathrm{~B}$ and $\mathrm{C}$ reveal the growth inhibitory effects of inducing p15INK4B on rapidly proliferating DF-1 cells compared to control groups. Further cellular, molecular, biochemical characterization of specific factors to modulate cellular characteristics for DF-1 cells remains for future studies.

\section{Conclusions}

In this study, we have demonstrated changes in genomewide gene expression for the immortal DF-1 CEF cell line showing rapid growth potential and chromosomal rearrangement. Taken together, the DF-1 genome sequence, which will be announced in the near future, and the differentially expressed genes characterized here provide transcriptional insights into the regulatory mechanisms for the unique characteristics observed in immortal DF-1 CEF cells.

\section{Methods}

\section{Cell culture}

Cell culture reagents were purchased from Invitrogen Life Technologies (Carlsbad, CA). Primary chicken CEF cells were isolated from 10 day old specific-pathogen free (SPF) chicken embryos (Charles River Laboratories, North Franklin, CT). Whole embryos were dissociated into single cell populations using $0.25 \%$ trypsin $/ 1 \mathrm{mM}$ EDTA. Cells dissociated from embryos were suspended in a Dulbecco's Modified Eagle's Medium (DMEM, $0.45 \%$ glucose) plus $10 \%$ fetal bovine serum (FBS), 100 units $/ \mathrm{ml}$ penicillin, $100 \mu \mathrm{g} / \mathrm{ml}$ streptomycin, and $2 \mathrm{mM}$ L-glutamine in $10 \mathrm{~cm}$ tissue culture dishes (Sarstedt Inc., Newton, NC). Cultured cells were grown at $39^{\circ} \mathrm{C}$ in a $5 \% \mathrm{CO}_{2}$ incubator until cells reached confluent monolayers ( 2 to 4 days) and primary CEF cells were passaged every 3-4 days and frozen stocks of cells were prepared from each passage at a density of $3 \times 10^{6}$ cells and stored in liquid nitrogen. Cell freezing medium was 
prepared by the addition of $40 \%$ FBS to growth media supplemented with $10 \%$ DMSO. The immortal DF-1 CEF cell line was grown using the same conditions as for primary CEF cells. All procedures of handling chicken embryos, cell cultures, and DNA/RNA were approved by Institutional Biosafety Committee (IBC: protocol number: 10007) of University of Arkansas.

\section{Total RNA extraction}

Total RNA was extracted from primary (passage 4) and DF-1 (passage 285) CEF cells using TRIzol reagent (Invitrogen Life Technologies, Carlsbad, CA) following the manufacturer's instructions. Total RNA was treated with DNase I (New England BioLabs Inc., Ipswich, MA), and RNA was re-purified by TRIzol reagent. The quality of RNA was checked by agarose gel electrophoresis fractionation (data not shown).

\section{Probe labeling and microarray hybridization}

A two color labeling microarray system was used to compare mRNA expression between primary and DF1 CEF cells. Fluorescently labeled complementary RNA (cRNA) probes were generated by using the Two Color Microarray Quick Labeling kit (Agilent Technologies, Palo Alto, CA) following the manufacturer's instructions. RNA Spike-in controls were used to adjust possible dye effects following the manufacturer's instructions. The Spike-in controls represent two sets of ten synthesized RNA mixtures derived from the Adenovirus E1A transcriptome with different concentrations in each set $[69,70]$. These Spike-in sets were mixed with either primary or DF-1 CEF samples and co-hybridized to the arrays. Briefly, $2 \mu \mathrm{g}$ of total RNA was mixed with Spike-in controls and converted to cDNA using reverse transcriptase and oligo dT primers in which T7 promoter sequences were added. T7 RNA polymerase was used for the synthesis and labeling of cRNA with either Cy3 dye for the primary CEF control or Cy5 dye for DF-1 CEF samples. The fluorescently labeled cRNA probes were purified using the Qiagen RNeasy Mini Kit (Qiagen Inc., Valencia, CA), and the concentration, fluorescent intensities, and quality of labeled cRNA probes were determined using a Nano-drop spectrophotometer (Thermo Scientific, Wilmington, DE). An equal amount (825 ng) of Cy3 and Cy5 labeled cRNA probes were hybridized on a 4 $\times 44 \mathrm{~K}$ Agilent chicken oligo microarray (array ID: 015068). The hybridized slide was washed using a commercial kit package (Agilent Technologies, Palo Alto, CA) and then scanned using a Genepix 4000B scanner (Molecular Devices Corporation, Sunnyvale, CA) with the tolerance of saturation setting of $0.005 \%$. Four biological replicates for each cell line were conducted.

\section{Microarray data collection and analysis}

Background-corrected red and green intensities were normalized by the local polynomial regression (loess) method. The average values of the resulting normalized expression in replicate hybridization sets were considered in the subsequent analysis. In order to identify differentially expressed genes, moderated t-statistic and its corresponding p-value based on empirical Bayes methods [71] for each gene were computed. The genes with both a p-value below 0.05 and fold change over \pm 2 fold were considered as statistically different between two groups and identified as differentially expressed genes. Results were deposited into Gene Expression Omnibus (GEO; accession number: GSE29257). All analyses were implanted in Microsoft Excel and JMP Genomics (SAS Institute, Cary, NC), which is licensed to Cell and Molecular Biology Program of University of Arkansas.

\section{Quantitative reverse transcription-polymerase chain reaction (qPCR)}

Reverse transcription was performed with $3 \mu \mathrm{g}$ of total RNA using Superscript II reverse transcriptase and oligo $\mathrm{dT}_{12-18}$ primers (Invitrogen Life Technologies, Carlsbad, CA) following the manufacturer's instructions. The reverse-transcribed CDNA was diluted by 1:10 ratio and a portion $(1 \mu \mathrm{l})$ was subjected to qPCR under the following conditions: 40 cycles of $95^{\circ} \mathrm{C}$ for $30 \mathrm{~s}$, gene-specific annealing temperature $\left(58-65^{\circ} \mathrm{C}\right)$ for $1 \mathrm{~min}$, extension for $30 \mathrm{~s}$ at $72^{\circ} \mathrm{C}$, and a final extension at $72^{\circ} \mathrm{C}$ for $10 \mathrm{~min}$. A non-template control and endogenous loading control (chicken GAPDH) were used for the relative quantification. The differential expression in DF-1 CEF cells were calculated by the $-\Delta \Delta C T$ method, which is comparable to $\log _{2}$ value of differentially expressed genes, against the primary CEF counterpart [72]. Primers for qPCR were designed using Primer3 software http://frodo.wi.mit.edu/cgi-bin/primer3/primer3.cgi and were synthesized by Integrated DNA Technologies (Coralville, IA). Primer information is listed in Table 5. All qPCR reactions were performed three times.

\section{Bioinformatics}

Functional interpretation of differentially expressed genes was analyzed in the context of gene ontology and molecular networks using the Ingenuity Pathways Analysis (IPA; Ingenuity Systems ${ }^{\circledR}$; http://www.ingenuity.com). Since IPA is based on human and mouse bioinformatics, functionalities for differentially expressed genes in the chicken were interpreted based primarily on mammalian biological mechanisms. The differentially expressed genes were compared to genetic categories in the IPA database, and ranked 
Table 5 Primers used for qRT-PCR

\begin{tabular}{|c|c|c|}
\hline Accession \# & $\begin{array}{l}\text { Forward Primer }\left(5^{\prime} \rightarrow 3^{\prime}\right) \\
\text { Reverse Primer }\left(5^{\prime} \rightarrow 3^{\prime}\right)\end{array}$ & Gene Symbol \\
\hline AB109635 & $\begin{array}{l}\text { GGCACCAACTTGCTACCACA } \\
\text { GCTGCAAGAGCTGCCATTAG }\end{array}$ & HMGCR \\
\hline AB196971 & $\begin{array}{l}\text { AGTGATGGGCGGAACAGAGT } \\
\text { GTCTTGCTGCACACCGACTT }\end{array}$ & APCDD1 \\
\hline AF505881 & $\begin{array}{l}\text { CCAGCTACATCTCCCACCTG } \\
\text { TCTGTTTGGGCTGGGAGTTC }\end{array}$ & SCX \\
\hline AJ131110 & $\begin{array}{l}\text { GTGGATAGCTTGGGGACCAG } \\
\text { AAGACTGGGAGCTGGGACTG }\end{array}$ & TWIST2 \\
\hline BU279212 & $\begin{array}{l}\text { GGCAACCATTITGATCTTGCT } \\
\text { CCCCTGCAAAAGCTGAAATC }\end{array}$ & CBLN2 \\
\hline BX929635 & $\begin{array}{l}\text { TCTCGCTCCTGGCAATGATA } \\
\text { CCAGCAGCACCATCTTTGAG }\end{array}$ & NDP \\
\hline BX931599 & $\begin{array}{l}\text { CTGTTTCCTGACCGCAGTTC } \\
\text { AGCACAAACTCCGCCATTIT }\end{array}$ & VIPR2 \\
\hline BX932694 & $\begin{array}{l}\text { GGCCCCTTACTGGTGGTCTT } \\
\text { AGACGGGCTITGGATAGCAA }\end{array}$ & MPZL2 \\
\hline BX933478 & $\begin{array}{l}\text { CCTGTGCAAGGTGTCCAGTG } \\
\text { CCCAATGGCCATACAGTTCA }\end{array}$ & MXRA5 \\
\hline BX933888 & $\begin{array}{l}\text { CTGGGATCCCTCCAGAGCTA } \\
\text { CCATTCACTGGAGCACCAAA }\end{array}$ & C1QTNF3 \\
\hline BX935456 & $\begin{array}{l}\text { CGAGGCCATCAACTTCCTTC } \\
\text { TCCACATGACGCACATACCC }\end{array}$ & EGLN3 \\
\hline BX936211 & $\begin{array}{l}\text { CCAGCTGTCCTCCTTGGAAT } \\
\text { AGGGAGAGGAAGACGTGCTG }\end{array}$ & TMEM116 \\
\hline CK611983 & $\begin{array}{l}\text { ATGATGACTGGGGGCTTGTC } \\
\text { GCAACCACTTGAGTCCGGTA }\end{array}$ & CSTA \\
\hline CR385566 & $\begin{array}{l}\text { CGCGCTCTACGACTACATGC } \\
\text { CTGGGTGGTGATCTCGGTCT }\end{array}$ & CLEC3B \\
\hline D87992 & $\begin{array}{l}\text { TGCAGCACTGAGACCTGGAT } \\
\text { CAGTTGCTGCGGATGAAGTC }\end{array}$ & ANPEP \\
\hline M60853 & $\begin{array}{l}\text { TTTGGCTACCAGTCCAGCA } \\
\text { TTCGCAAGTGTTCCCCAGTA }\end{array}$ & THBS2 \\
\hline M64990 & $\begin{array}{l}\text { TGCTCCCCTGAGTACTGGAA } \\
\text { GCCTCTGTGGGTTCAGGATT }\end{array}$ & PTGS2 \\
\hline M80584 & $\begin{array}{l}\text { TCCCACTGAGCAGCTTCTGTA } \\
\text { CCAGAGAGATATCCGCAGCA }\end{array}$ & LUM \\
\hline M87294 & $\begin{array}{l}\text { GGTGCTGACTITCGCCTTGT } \\
\text { GCCTGGTGATGAGGTTGATG }\end{array}$ & NPY \\
\hline X87609 & $\begin{array}{l}\text { CCACCTGAGAAAAGCGACCT } \\
\text { ACATCGACCTCTGCCAACCT }\end{array}$ & FST \\
\hline NM_204305 & $\begin{array}{l}\text { GGCACTGTCAAGGCTGAGAA } \\
\text { TGCATCTGCCCATTTGATGT }\end{array}$ & chGAPDH \\
\hline
\end{tabular}

The first column indicates the NCBI accession number for designated genes, and the second column shows sequences for the forward and reverse primers. The gene symbols are provided in the third column.

according to p-values [73]. Since the size of the created gene network could potentially be enormous, the number of molecules in the network was set to the limit of 35 , leaving only the most important ones based on the number of connections for each focus gene (focus genes $=$ a subset of uploaded significant genes having direct interactions with other genes in the database) to other significant genes [74].

\section{Additional material}

Additional file 1: List of entire 3876 DE genes before sorting by IPA. The values indicate $\log _{2}$ fold changes. The Agilent ID, gene symbol, gene name, GenBank accession numbers, chromosomal region, cytoband, GO ID, and oligo sequence on the array were provided.

Additional file 2: List of 902 DE genes identified by IPA database. The values indicate $\log _{2}$ fold changes. The gene symbol, gene name, GenBank accession numbers, cellular locations, and molecule types were provided.

Additional file 3: List of focus molecules in gene networks. Gene symbols and GenBank accession numbers were displayed for the illustrations of network analysis. Only focus molecules, which were elected as differentially expressed genes from microarray analysis, include GenBank accession numbers, while accession numbers for reference molecules were not shown in the table.

Additional file 4: DF-1 cell growth responding to siRNA for E2F-1, BRCA1, and SRC. Each of four small siRNAs to target chE2F1 (A), chBRCA1 (B), chSRC (C), and chBeta-actin (D), in addition to a negative control siRNA were synthesized by Integrated DNA Technology Inc. (Coralville, IA). One million DF-1 cells were transfected with 300 pmole of each siRNA using Lipofectamine reagent (Invitrogen Life Technologies, Carlsbad, CA). Transfected cells were collected at 1 and 3 days post transfection (dpt), total cell numbers were counted, and the growth rates were determined by ratio of cell numbers at $3 \mathrm{dpt}$ and cell numbers at $1 \mathrm{dpt}$. Results were compared to a negative control. Results of the most effective siRNA for each target were displayed. The siRNA for chBetaactin was used as positive control to suppress DF-1 cell growth.

Additional file 5: DF-1 cell growth responding to 5-aza-2'-

deoxycytidine treatment for the induction of p15INK4B. A $2 \mu \mathrm{M}$ concentration of 5-aza-2'-deoxycytidine (5-aza), which is a demethylation chemical, was used to treat 1 million DF-1 cells, cells which were collected at 1, 2, 3, and 4 days post treatment. The mRNA expression of p15INK4B was determined by qRT-PCR at designated time points (A); cell morphology was visualized by phase-contrast microscopy $(400 \times$; B); and cell numbers were counted to determine growth rates (C).

\section{Acknowledgements}

This work was supported by Arkansas Bioscience Institute and, in part, by Arkansas Agricultural Experimental Station.

\section{Author details}

${ }^{1}$ Department of Poultry Science, Center of Excellence for Poultry Science, University of Arkansas, Fayetteville, Arkansas 72701, USA. ²Department of Chemistry, Purdue University, West Lafayette, IN 47907, USA. ${ }^{3}$ Department of Animal Science, University of Minnesota, St. Paul, MN 55108, USA.

\section{Authors' contributions}

BWK and JYL designed the experiments, performed the experiments, analyzed the data, and wrote the manuscript. WB and KL contributed to the interpretation of the bioinformatics analysis and manuscript editing. JL analyzed the GPCR assay and DNF prepared DF-1 cells and edited the manuscript preparation. All authors read and approved the final manuscript.

Received: 18 July 2011 Accepted: 23 November 2011 Published: 23 November 2011

\section{References}

1. Hayflick L, Moorhead PS: The serial cultivation of human diploid cell strains. Exp Cell Res 1961, 25:585-621.

2. Sedivy JM: Can ends justify the means?: telomeres and the mechanisms of replicative senescence and immortalization in mammalian cells. Proc Natl Acad Sci USA 1998, 95:9078-81.

3. Aviv A, Harley CB: How long should telomeres be? Curr Hypertens Rep 2001, 3:145-51.

4. Sherr CJ, DePinho RA: Cellular senescence: mitotic clock or culture shock? Cell 2000, 102:407-10. 
5. Bacon LD, Hunt HD, Cheng HH: A review of the development of chicken lines to resolve genes determining resistance to diseases. Poult Sci 2000, 79:1082-93.

6. Himly M, Foster DN, Bottoli I, lacovoni JS, Vogt PK: The DF-1 chicken fibroblast cell line: transformation induced by diverse oncogenes and cell death resulting from infection by avian leukosis viruses. Virology 1998, 248:295-304

7. Schaefer-Klein J, Givol I, Barsov EV, Whitcomb JM, VanBrocklin M, Foster DN, Federspiel MJ, Hughes SH: The EV-O-derived cell line DF-1 supports the efficient replication of avian leukosis-sarcoma viruses and vectors. Virology 1998, 248:305-11.

8. Maas R, van Zoelen D, Oei H, Claassen I: Replacement of primary chicken embryonic fibroblasts (CEF) by the DF-1 cell line for detection of avian leucosis viruses. Biologicals 2006, 34:177-81.

9. Levy AM, Gilad O, Xia L, Izumiya Y, Choi J, Tsalenko A, Yakhini Z, Witter R, Lee L, Cardona CJ, Kung HJ: Marek's disease virus Meq transforms chicken cells via the v-Jun transcriptional cascade: a converging transforming pathway for avian oncoviruses. Proc Natl Acad Sci USA 2005, 102:14831-6.

10. Lee CW, Jung K, Jadhao SJ, Suarez DL: Evaluation of chicken-origin (DF-1) and quail-origin (QT-6) fibroblast cell lines for replication of avian influenza viruses. J Virol Methods 2008, 153:22-8.

11. Moresco KA, Stallknecht DE, Swayne DE: Evaluation and attempted optimization of avian embryos and cell culture methods for efficient isolation and propagation of low pathogenicity avian influenza viruses. Avian Dis 2010, 54:622-6.

12. Wang $Y$, Qi X, Gao H, Gao Y, Lin H, Song X, Pei L, Wang X: Comparative study of the replication of infectious bursal disease virus in DF-1 cell line and chicken embryo fibroblasts evaluated by a new real-time RTPCR. J Virol Methods 2009, 157:205-10.

13. Kong BW, Foster LK, Foster DN: Comparison of avian cell substrates for propagating subtype C avian metapneumovirus. Virus Res 2006, 116:58-68.

14. Tiwari A, Patnayak DP, Chander Y, Goyal SM: Permissibility of different cell types for the growth of avian metapneumovirus. J Virol Methods 2006 138:80-4.

15. Kong BW, Foster LK, Foster DN: Establishment of an immortal turkey turbinate cell line suitable for avian metapneumovirus propagation. Virus Res 2007, 127:106-15.

16. Kim H, You S, Kim IJ, Farris J, Foster LK, Foster DN: Increased mitochondrial-encoded gene transcription in immortal DF-1 cells. Exp Cell Res 2001, 265:339-47

17. Christman SA, Kong BW, Landry MM, Kim H, Foster DN: Contributions of differential p53 expression in the spontaneous immortalization of a chicken embryo fibroblast cell line. BMC Cell Biol 2006, 7:27.

18. O'Hare TH, Delany ME: Genetic variation exists for telomeric array organization within and among the genomes of normal, immortalized, and transformed chicken systems. Chromosome Res 2009, 17:947-64.

19. Kim H, You S, Kim IJ, Foster LK, Farris J, Ambady S, Ponce de Leon FA, Foster DN: Alterations in p53 and E2F-1 function common to immortalized chicken embryo fibroblasts. Oncogene 2001, 20:2671-82.

20. Kim H, You S, Kong BW, Foster LK, Farris J, Foster DN: Necrotic cell death by hydrogen peroxide in immortal DF-1 chicken embryo fibroblast cells expressing deregulated MnSOD and catalase. Biochim Biophys Acta 2001, 1540:137-46.

21. Kong BW, Kim H, Foster DN: Expression analysis and mitochondrial targeting properties of the chicken manganese-containing superoxide dismutase. Biochim Biophys Acta 2003, 1625:98-108.

22. You S, Kong BW, Jeon SY, Foster DN, Kim H: Deregulation of catalase, not $\mathrm{MnSOD}$, is associated with necrotic death of p53-defective DF-1 cells under antimycin A-induced oxidative stress. Mol Cells 2004, 18:220-9.

23. Taniguchi Y, Choi PJ, Li GW, Chen H, Babu M, Hearn J, Emili A, Xie XS: Quantifying E. coli proteome and transcriptome with single-molecule sensitivity in single cells. Science 2010, 329:533-8.

24. Greenbaum D, Colangelo C, Williams K, Gerstein M: Comparing protein abundance and mRNA expression levels on a genomic scale. Genome Biol 2003, 4:117

25. Pascal LE, True LD, Campbell DS, Deutsch EW, Risk M, Coleman IM, Eichner LJ, Nelson PS, Liu AY: Correlation of mRNA and protein levels: cell type-specific gene expression of cluster designation antigens in the prostate. BMC Genomics 2008, 9:246.
26. Guo Y, Xiao P, Lei S, Deng F, Xiao GG, Liu Y, Chen X, Li L, Wu S, Chen Y, Jiang $H$, Tan $L$, Xie J, Zhu $X$, Liang $S$, Deng $H$ : How is mRNA expression predictive for protein expression? A correlation study on human circulating monocytes. Acta Biochim Biophys Sin (Shanghai) 2008, 40:426-36.

27. Nie L, Wu G, Zhang W: Correlation of mRNA expression and protein abundance affected by multiple sequence features related to translational efficiency in Desulfovibrio vulgaris: a quantitative analysis. Genetics 2006, 174:2229-43.

28. Brehm A, Miska EA, McCance DJ, Reid JL, Bannister AJ, Kouzarides T: Retinoblastoma protein recruits histone deacetylase to repress transcription. Nature 1998, 391:597-601.

29. Cai J, Yao N, Gibbs E, Finkelstein J, Phillips B, O'Donnell M, Hurwitz J: ATP hydrolysis catalyzed by human replication factor $C$ requires participation of multiple subunits. Proc Natl Acad Sci USA 1998, 95:11607-12.

30. Khanna KK, Jackson SP: DNA double-strand breaks: signaling, repair and the cancer connection. Nat Genet 2001, 27:247-54.

31. Larsen E, Gran C, Saether BE, Seeberg E, Klungland A: Proliferation failure and gamma radiation sensitivity of Fen 1 null mutant mice at the blastocyst stage. Mol Cell Biol 2003, 23:5346-53.

32. Wang Y, Cortez D, Yazdi P, Neff N, Elledge SJ, Qin J: BASC, a super complex of BRCA1-associated proteins involved in the recognition and repair of aberrant DNA structures. Genes Dev 2000, 14:927-39.

33. Cui Y, Wang J, Zhang X, Lang R, Bi M, Guo L, Lu SH: ECRG2, a novel candidate of tumor suppressor gene in the esophageal carcinoma, interacts directly with metallothionein $2 \mathrm{~A}$ and links to apoptosis. Biochem Biophys Res Commun 2003, 302:904-15.

34. Salehi AH, Xanthoudakis S, Barker PA: NRAGE, a p75 neurotrophin receptor-interacting protein, induces caspase activation and cell death through a JNK-dependent mitochondrial pathway. J Biol Chem 2002, 277:48043-50.

35. Degterev A, Boyce M, Yuan J: A decade of caspases. Oncogene 2003, 22:8543-67.

36. Shi Y: Mechanisms of caspase activation and inhibition during apoptosis. Mol Cell 2002, 9:459-70

37. Chung MT, Lai HC, Sytwu HK, Yan MD, Shih YL, Chang CC, Yu MH, Liu HS, Chu DW, Lin YW: SFRP1 and SFRP2 suppress the transformation and invasion abilities of cervical cancer cells through Wnt signal pathway. Gynecol Oncol 2009, 112:646-53.

38. Han X, Amar S: Secreted frizzled-related protein 1 (SFRP1) protects fibroblasts from ceramide-induced apoptosis. J Biol Chem 2004, 279:2832-40.

39. Lin KR, Lee SF, Hung CM, Li CL, Yang-Yen HF, Yen JJ: Survival factor withdrawal-induced apoptosis of TF-1 cells involves a TRB2-Mcl-1 axisdependent pathway. J Biol Chem 2007, 282:21962-72.

40. Xie J, Guo Q: AATF protects neural cells against oxidative damage induced by amyloid beta-peptide. Neurobiol Dis 2004, 16:150-7.

41. Wohlschlegel JA, Dwyer BT, Dhar SK, Cvetic C, Walter JC, Dutta A: Inhibition of eukaryotic DNA replication by geminin binding to Cdt1. Science 2000, 290:2309-12.

42. Tada S, Li A, Maiorano D, Mechali M, Blow JJ: Repression of origin assembly in metaphase depends on inhibition of RLF-B/Cdt1 by geminin. Nat Cell Biol 2001, 3:107-13.

43. Roukos V, lliou MS, Nishitani H, Gentzel M, Wilm M, Taraviras S, Lygerou Z: Geminin cleavage during apoptosis by caspase- 3 alters its binding ability to the SWI/SNF subunit Brahma. J Biol Chem 2007, 282:9346-57.

44. Zhu W, Depamphilis ML: Selective killing of cancer cells by suppression of geminin activity. Cancer Res 2009, 69:4870-7.

45. Ramachandran N, Hainsworth E, Bhullar B, Eisenstein S, Rosen B, Lau AY, Walter JC, LaBaer J: Self-assembling protein microarrays. Science 2004, 305:86-90.

46. Maiorano D, Lutzmann M, Mechali M: MCM proteins and DNA replication. Curr Opin Cell Biol 2006, 18:130-6.

47. Sakwe AM, Nguyen T, Athanasopoulos V, Shire K, Frappier L: Identification and characterization of a novel component of the human minichromosome maintenance complex. Mol Cell Biol 2007, 27:3044-55.

48. Weinmann AS, Yan PS, Oberley MJ, Huang TH, Farnham PJ: Isolating human transcription factor targets by coupling chromatin immunoprecipitation and CpG island microarray analysis. Genes Dev 2002, 16:235-44. 
49. Dyson N: The regulation of E2F by pRB-family proteins. Genes Dev 1998, 12:2245-62.

50. Schaarschmidt D, Ladenburger EM, Keller C, Knippers R: Human Mcm proteins at a replication origin during the $\mathrm{G} 1$ to $\mathrm{S}$ phase transition. Nucleic Acids Res 2002, 30:4176-85.

51. Vashee $S$, Simancek $P$, Challberg MD, Kelly TJ: Assembly of the human origin recognition complex. J Biol Chem 2001, 276:26666-73.

52. Gruneberg U, Neef R, Li X, Chan EH, Chalamalasetty RB, Nigg EA, Barr FA: KIF14 and citron kinase act together to promote efficient cytokinesis. $J$ Cell Biol 2006, 172:363-72.

53. Lee KS, Yuan YL, Kuriyama R, Erikson RL: Plk is an M-phase-specific protein kinase and interacts with a kinesin-like protein, CHO1/MKLP-1. Mol Cell Biol 1995, 15:7143-51.

54. Santamaria A, Wang B, Elowe S, Malik R, Zhang F, Bauer M, Schmidt A, Sillje HH, Korner R, Nigg EA: The Plk1-dependent phosphoproteome of the early mitotic spindle. Mol Cell Proteomics 2011, 10:M110.004457.

55. Liang J, Pan Y, Zhang D, Guo C, Shi Y, Wang J, Chen Y, Wang X, Liu J, Guo X, Chen Z, Qiao T, Fan D: Cellular prion protein promotes proliferation and G1/S transition of human gastric cancer cells SGC7901 and AGS. FASEB J 2007, 21:2247-56.

56. De Wulf $P$, McAinsh AD, Sorger PK: Hierarchical assembly of the budding yeast kinetochore from multiple subcomplexes. Genes Dev 2003, 17:2902-21.

57. Wigge PA, Kilmartin JV: The Ndc80p complex from Saccharomyces cerevisiae contains conserved centromere components and has a function in chromosome segregation. J Cell Biol 2001, 152:349-60.

58. Fernandez-Martinez AB, Bajo AM, Isabel Arenas M, Sanchez-Chapado M, Prieto JC, Carmena MJ: Vasoactive intestinal peptide (VIP) induces malignant transformation of the human prostate epithelial cell line RWPE-1. Cancer Lett 2010, 299:11-21.

59. Yuste L, Montero JC, Esparis-Ogando A, Pandiella A: Activation of ErbB2 by overexpression or by transmembrane neuregulin results in differential signaling and sensitivity to herceptin. Cancer Res 2005, 65:6801-10.

60. Feutz AC, Barrandon Y, Monard D: Control of thrombin signaling through $\mathrm{PI} 3 \mathrm{~K}$ is a mechanism underlying plasticity between hair follicle dermal sheath and papilla cells. J Cell Sci 2008, 121::1435-43.

61. Zhang Y, Kornfeld H, Cruikshank WW, Kim S, Reardon CC, Center DM: Nuclear translocation of the N-terminal prodomain of interleukin-16. J Biol Chem 2001, 276:1299-303.

62. Cooper JA, Howell B: The when and how of Src regulation. Cell 1993, 73:1051-4.

63. Lee H, Park DS, Wang XB, Scherer PE, Schwartz PE, Lisanti MP: Src-induced phosphorylation of caveolin-2 on tyrosine 19. Phospho-caveolin-2 (Tyr(P) 19) is localized near focal adhesions, remains associated with lipid rafts/ caveolae, but no longer forms a high molecular mass hetero-oligomer with caveolin-1. J Biol Chem 2002, 277:34556-67.

64. Zhang J, Wong CH, Xia W, Mruk DD, Lee NP, Lee WM, Cheng CY: Regulation of Sertoli-germ cell adherens junction dynamics via changes in protein-protein interactions of the $\mathrm{N}$-cadherin-beta-catenin protein complex which are possibly mediated by c-Src and myotubularin-related protein 2: an in vivo study using an androgen suppression model. Endocrinology 2005, 146:1268-84.

65. Wu C, Ma MH, Brown KR, Geisler M, Li L, Tzeng E, Jia CY, Jurisica I, Li SS: Systematic identification of $\mathrm{SH} 3$ domain-mediated human proteinprotein interactions by peptide array target screening. Proteomics 2007, 7:1775-85.

66. Liu M, Post M: Invited review: mechanochemical signal transduction in the fetal lung. J Appl Physiol 2000, 89:2078-84.

67. Kawasaki BT, Liao Y, Birnbaumer L: Role of Src in C3 transient receptor potential channel function and evidence for a heterogeneous makeup of receptor- and store-operated Ca2+ entry channels. Proc Natl Acad SCi USA 2006, 103:335-40.

68. Wu L, Timmers C, Maiti B, Saavedra HI, Sang L, Chong GT, Nuckolls F, Giangrande P, Wright FA, Field SJ, Greenberg ME, Orkin S, Nevins JR, Robinson ML, Leone G: The E2F1-3 transcription factors are essential for cellular proliferation. Nature 2001, 414:457-62.

69. Zahurak M, Parmigiani G, Yu W, Scharpf RB, Berman D, Schaeffer E, Shabbeer S, Cope L: Pre-processing Agilent microarray data. BMC Bioinformatics 2007, 8:142.

70. Lee JY, Song JJ, Wooming A, Li X, Zhou H, Bottje WG, Kong BW: Transcriptional profiling of host gene expression in chicken embryo lung cells infected with laryngotracheitis virus. BMC Genomics 2010, 11:445.

71. Smyth GK: Linear models and empirical bayes methods for assessing differential expression in microarray experiments. Stat Appl Genet Mol Biol 2004, 3:Article3.

72. Livak KJ, Schmittgen TD: Analysis of relative gene expression data using real-time quantitative PCR and the 2(-Delta Delta C(T)) Method. Methods 2001, 25:402-8.

73. Mori R, Xiong S, Wang Q, Tarabolous C, Shimada H, Panteris E, Danenberg KD, Danenberg PV, Pinski JK: Gene profiling and pathway analysis of neuroendocrine transdifferentiated prostate cancer cells. Prostate 2009, 69:12-23.

74. Calvano SE, Xiao W, Richards DR, Felciano RM, Baker HV, Cho RJ, Chen RO, Brownstein BH, Cobb JP, Tschoeke SK, Miller-Graziano C, Moldawer LL, Mindrinos MN, Davis RW, Tompkins RG, Lowry SF: A network-based analysis of systemic inflammation in humans. Nature 2005, 437:1032-7.

75. Takahashi M, Fujita M, Furukawa Y, Hamamoto R, Shimokawa T, Miwa N, Ogawa M, Nakamura Y: Isolation of a novel human gene, APCDD1, as a direct target of the beta-Catenin/T-cell factor 4 complex with probable involvement in colorectal carcinogenesis. Cancer Res 2002, 62:5651-6.

76. Murakami M, Ohkuma M, Nakamura M: Molecular mechanism of transforming growth factor-beta-mediated inhibition of growth arrest and differentiation in a myoblast cell line. Dev Growth Differ 2008, 50:121-30

77. Wellcome Trust Case Control Consortium: Genome-wide association study of 14,000 cases of seven common diseases and 3,000 shared controls. Nature 2007, 447:661-78.

78. Krenz M, Sadayappan S, Osinska HE, Henry JA, Beck S, Warshaw DM, Robbins J: Distribution and structure-function relationship of myosin heavy chain isoforms in the adult mouse heart. J Biol Chem 2007, 282:24057-64.

79. Jones WK, Grupp IL, Doetschman T, Grupp G, Osinska H, Hewett TE, Boivin G, Gulick J, Ng WA, Robbins J: Ablation of the murine alpha myosin heavy chain gene leads to dosage effects and functional deficits in the heart. J Clin Invest 1996, 98:1906-17.

80. Hara H, Bakal C, Wada T, Bouchard D, Rottapel R, Saito T, Penninger JM: The molecular adapter Carma1 controls entry of IkappaB kinase into the central immune synapse. J Exp Med 2004, 200:1167-77.

81. Hu MH, Bauman EM, Roll RL, Yeilding N, Abrams CS: Pleckstrin 2, a widely expressed paralog of pleckstrin involved in actin rearrangement. J Biol Chem 1999, 274:21515-8.

82. Wang T, Xia D, Li N, Wang C, Chen T, Wan T, Chen G, Cao X: Bone marrow stromal cell-derived growth inhibitor inhibits growth and migration of breast cancer cells via induction of cell cycle arrest and apoptosis. J Biol Chem 2005, 280:4374-82.

83. Kawai T, Suzuki Y, Eda S, Kase T, Ohtani K, Sakai Y, Keshi H, Fukuoh A, Sakamoto T, Nozaki M, Copeland NG, Jenkins NA, Wakamiya N: Molecular cloning of mouse collectin liver 1. Biosci Biotechnol Biochem 2002, 66:2134-45.

84. Konig R, Stertz S, Zhou Y, Inoue A, Hoffmann HH, Bhattacharyya S, Alamares JG, Tscherne DM, Ortigoza MB, Liang Y, Gao Q, Andrews SE, Bandyopadhyay S, De Jesus P, Tu BP, Pache L, Shih C, Orth A, Bonamy G, Miraglia L, Ideker T, Garcia-Sastre A, Young JA, Palese P, Shaw ML, Chanda SK: Human host factors required for influenza virus replication. Nature 2010, 463:813-7.

85. Satow R, Shitashige M, Kanai Y, Takeshita F, Ojima H, Jigami T, Honda K, Kosuge T, Ochiya T, Hirohashi S, Yamada T: Combined functional genome survey of therapeutic targets for hepatocellular carcinoma. Clin Cancer Res 2010, 16:2518-28

86. Kamio M, Yoshida T, Ogata $H$, Douchi T, Nagata $Y$, Inoue M, Hasegawa M, Yonemitsu Y, Yoshimura A: SOCS1 inhibits HPV-E7-mediated transformation by inducing degradation of E7 protein. Oncogene 2004, 23:3107-15.

87. Kolehmainen J, Black GC, Saarinen A, Chandler K, Clayton-Smith J, Traskelin AL, Perveen R, Kivitie-Kallio S, Norio R, Warburg M, Fryns JP, de la Chapelle A, Lehesjoki AE: Cohen syndrome is caused by mutations in a novel gene, $\mathrm{COH} 1$, encoding a transmembrane protein with a presumed role in vesicle-mediated sorting and intracellular protein transport. Am J Hum Genet 2003, 72:1359-69. 
88. Scholz G, Martinerie C, Perbal B, Hanafusa H: Transcriptional down regulation of the nov proto-oncogene in fibroblasts transformed by p60v-src. Mol Cell Biol 1996, 16:481-6.

89. Yu C, Le AT, Yeger H, Perbal B, Alman BA: NOV (CCN3) regulation in the growth plate and CCN family member expression in cartilage neoplasia. J Pathol 2003, 201:609-15.

90. Zamora M, Merono C, Vinas O, Mampel T: Recruitment of NF-kappaB into mitochondria is involved in adenine nucleotide translocase 1 (ANT1)induced apoptosis. J Biol Chem 2004, 279:38415-23.

91. Roussel MF: The INK4 family of cell cycle inhibitors in cancer. Oncogene 1999, 18:5311-7.

92. Kim SH, Mitchell M, Fujii H, Llanos S, Peters G: Absence of p16INK4a and truncation of ARF tumor suppressors in chickens. Proc Natl Acad Sci USA 2003, 100:211-6.

93. Kim SH, Rowe J, Fujii H, Jones R, Schmierer B, Kong BW, Kuchler K, Foster D, Ish-Horowicz D, Peters G: Upregulation of chicken p15INK4b at senescence and in the developing brain. J Cell Sci 2006, 119:2435-43.

94. Van Dyken SJ, Green RS, Marth JD: Structural and mechanistic features of protein O glycosylation linked to CD8+ T-cell apoptosis. Mol Cell Biol 2007, 27:1096-111.

95. Fernandez-Martinez A, Molla B, Mayoral R, Bosca L, Casado M, MartinSanz P: Cyclo-oxygenase 2 expression impairs serum-withdrawal-induced apoptosis in liver cells. Biochem J 2006, 398:371-80.

96. Pyagay $\mathrm{P}$, Heroult $\mathrm{M}$, Wang $\mathrm{Q}$, Lehnert W, Belden J, Liaw L, Friesel RE, Lindner V: Collagen triple helix repeat containing 1, a novel secreted protein in injured and diseased arteries, inhibits collagen expression and promotes cell migration. Circ Res 2005, 96:261-8.

97. Noren NK, Pasquale EB: Eph receptor-ephrin bidirectional signals that target Ras and Rho proteins. Cell Signal 2004, 16:655-66.

98. Guo J, Chen S, Huang C, Chen L, Studholme DJ, Zhao S, Yu L: MANSC: a seven-cysteine-containing domain present in animal membrane and extracellular proteins. Trends Biochem Sci 2004, 29:172-4.

99. Rozengurt E, Walsh JH: Gastrin, CCK, signaling, and cancer. Annu Rev Physiol 2001, 63:49-76.

100. Yamada R, Mizutani-Koseki Y, Hasegawa T, Osumi N, Koseki H, Takahashi N Cell-autonomous involvement of Mab2111 is essential for lens placode development. Development 2003, 130:1759-70.

doi:10.1186/1471-2164-12-571

Cite this article as: Kong et al:: Genome-wide differential gene expression in immortalized DF-1 chicken embryo fibroblast cell line. BMC Genomics 2011 12:571.

\section{Submit your next manuscript to BioMed Central and take full advantage of:}

- Convenient online submission

- Thorough peer review

- No space constraints or color figure charges

- Immediate publication on acceptance

- Inclusion in PubMed, CAS, Scopus and Google Scholar

- Research which is freely available for redistribution

Submit your manuscript at www.biomedcentral.com/submit
Biomed Central 